U. S. DEPARTMENT OF THE INTERIOR

U.S. GEOLOGICAL SURVEY

\title{
GEOLOGIC MAP OF THE COLLEGIATE PEAKS WILDERNESS AREA AND THE GRIZZLY PEAK CALDERA, SAWATCH RANGE, CENTRAL COLORADO
}

By

C.J. Fridrich, Ed DeWitt, Bruce Bryant, Steve Richard, and R.P. Smith

MAP I-2565

1998 


\section{CONTENTS}

Explanatory notes 1

Description of Map Units 1

Acknowledgments 26

References Cited 26

\section{FIGURES}

3. Summary geochemical diagrams for rocks of the Grizzly Peak caldera. 2

4. Summary geochemical diagrams for Cretaceous and Tertiary intrusive rocks in the Aspen area. 6

5. Summary geochemical diagrams for the Italian Mountain intrusive complex. 7

6. Summary geochemical diagrams for altered intrusive rocks at Middle Mountain and Winfield Peak. 8

7. Summary geochemical diagrams for rocks of the Mount Champion area. 9

8. Summary geochemical diagrams for intrusive rocks of the Mount Princeton Pluton.

9. Summary geochemical diagrams for intrusive rocks of the Twin Lakes Pluton. 11

10. ${ }^{40} \mathrm{Ar}-{ }^{39} \mathrm{Ar}$ release spectra for hornblende from sample R8-28-84-4 of mafic border of Twin Lakes pluton. Width of bars on spectra is 2-sigma uncertainty.

13

11. Summary geochemical diagrams for Cretaceous plutons east of the Twin Lakes pluton. $\mathbf{1 5}$

12. Summary geochemical diagrams for $1.4-\mathrm{Ga}$ plutons and plutons assumed to be $1.4 \mathrm{Ga}$ in the central Sawatch Range area.

17

13. Concordia diagram for zircon from sample IC-6 of the St. Kevin Granite. Size of symbol represents 2-sigma analytical uncertainty.

14. Summary geochemical diagrams for some $1.65-\mathrm{Ga}$ and older plutons in the central Sawatch Range area. Plot includes the Kroenke Granodiorite, granite of Henry Mountain, and granite of Mount Yale. 21

15. Summary geochemical diagrams for some $1.70-\mathrm{Ga}$ and older plutons in the central Sawatch Range area. Plot includes the Denny Creek Granodiorite and unnamed gabbro. 


\section{EXPLANATORY NOTES}

In order to facilitate use of this large map, two smaller index maps have been prepared, a location map (fig. 1) that has place names used in the description of map units, and a simplified bedrock geologic map (fig. 2). The simplified geologic map consolidates the units within the description of map units and deletes all surficial, glacial, and Miocene and younger stratified deposits. The compositional names of all igneous rock units are based on the $R_{1} R_{2}$ nomenclature of De La Roche and others (1980). For rocks in the Grizzly Peak caldera, additional modifiers used are: low-silica for rhyolites with $<73 \% \mathrm{SiO}_{2}$ and high-silica for rhyolites with $>76.5 \% \mathrm{SiO}_{2}$. Supporting geochemical data for igneous units are shown in figures 3-15. Summary geochronologic data for samples from the map area are in table 1.

\section{DESCRIPTION OF MAP UNITS}

Qs

Surficial deposits (Holocene)-Alluvium, alluvial-fan deposits, talus, landslide deposits, colluvium, solifluction deposits, swamp deposits, rock glaciers, and rock avalanches younger than Pinedale glacial event. Locally contains small areas of ground moraine and lateral moraine. Surficial versus glacial deposits not differentiated in Italian Mountain area; all Quaternary deposits there designated as surficial. Small areas of bedrock that have moved during landsliding or glacial deposits that have slumped are not shown as surficial deposits; instead, fault symbols are shown at the head of such deposits

Og Glacial deposits (Pleistocene)-Glacial till, including ground, lateral, and terminal morainal deposits, and sand and gravel in deposits of Pinedale and older glacial events. Locally contains small areas of colluvium and till that has slumped

Tdu Dry Union Formation (Pliocene and Miocene)Light-brown, poorly consolidated sandy siltstone and interbedded friable sandstone, conglomerate, and volcanic ash. In map area, only present in the upper Arkansas River graben from east of Mount Elbert to south of Granite

Rock units of the Grizzly Peak caldera-Plutons of the Grizzly Peak caldera consist of three age groups. Late-resurgent and postresurgent plutons together form an east-west belt of dikes and stocks across the central part of the caldera. The oldest rocks are resurgent plutons of the composite laccolith in the north-central part of the caldera
Post-resurgent plutons (Oligocene)-Numerous dikes and small stocks ranging in composition from high-silica rhyolite to lati-andesite (monzodiorite) concentrated within the Grizzly Peak caldera. Rhyolite porphyry dikes are typically light greenish or bluish gray and strongly flow foliated. Rhyodacite dikes are much less numerous that rhyolite dikes and are medium gray or grayish green. Dacite and lati-andesite dikes are dark olive green or greenish black and commonly have boulder-size (to $>5 \mathrm{~m}$ ) inclusions of pink, medium-grained, nonfoliated granite. Also includes the composite Sawmill stock (Cruson, 1973), a 1.6-km-diameter, dark-greenish-gray to greenish-gray, porphyritic to equigranular tonalite near the ghost town of Ruby, in the center of the caldera, and a smaller stock southeast of Ruby, referred to as the Red Mountain stock (Holtzclaw, 1973). Many of the post-resurgent dikes are radial to the Sawmill stock. Rhyolite porphyries contain about 5\% phenocrysts of quartz, two feldspars, and biotite; rhyodacite and dacite porphyries contain $10-40 \%$ phenocrysts of plagioclase and biotite, thornblende; lati-andesite porphyries contain about $10 \%$ phenocrysts of plagioclase and lesser amounts of biotite. The Sawmill stock consists of a small body of phenocryst-poor rhyolite porphyry emplaced into a larger intrusive body that ranges from margins of phenocryst-rich porphyritic-aphanitic biotite-hornblende granodiorite porphyry to a core of nearly equigranular, fine- to medium-grained biotite tonalite.

Compositionally, the lati-andesite dikes are alkali-calcic, (fig. 3A), metaluminous (fig. 3B), have average alkali enrichment (fig. 3C), and average iron enrichment (fig. 3D). The most felsic dikes are also alkali-calcic (fig. $3 \mathrm{~A}$ ), are mildly peraluminous to strongly peraluminous (fig. 3B), have an average to sodic alkali enrichment (fig. 3C), and are $\mathrm{Mg}$-rich (fig. 3D). Some late dikes are marginally alkalic, because they have compositions of quartz latite (fig. $3 \mathrm{~A}$ ) and are very $\mathrm{Mg}$ rich (fig. 3D).

Oligocene age assignment for the Sawmill stock based on K-Ar biotite date of $32.9 \pm 1.1$ Ma (Fridrich and others, 1991)

\section{Resurgent plutons}

$\mathrm{TI} \quad$ Late-resurgent plutons (Oligocene)-Four stocks, each less than $1 \mathrm{~km}$ in diameter, and several related dikes. Stocks are on Pine Creek, at 


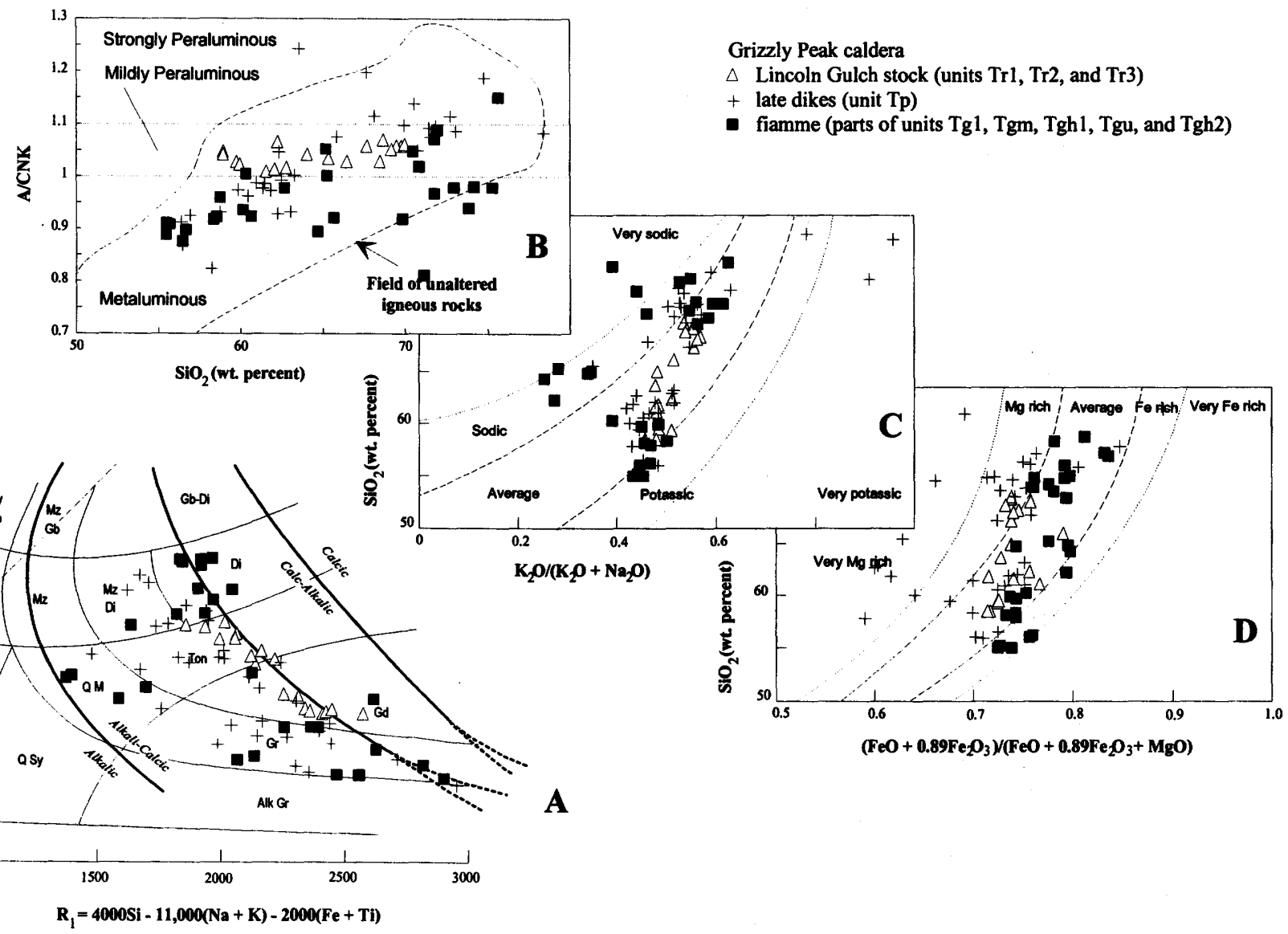

Figure 3. Summary geochemical diagrams for rocks of the Grizzly Peak caldera. Data from C.J. Fridrich (1986; unpub. data, 1994).

(A) $R_{1} R_{2}$ major element classification diagram (De la Roche and others, 1980). Alk Rhy, alkali rhyolite; Rhy, rhyolite; $R$ Dac, rhyodacite; Dac, dacite; And, Andesite; And-Bas, andesitic basalt; Lat And, lati-andesite; Q Lat, quartz latite; $Q \operatorname{Tr}$, quartz Trachyte; Tr, trachyte; Lat, latite; T Bas, trachybasalt; T And, trachyandesite; Lat Bas, latibasalt. Volcanic rock names used because of fine-grained nature of most rocks. See figure 4 for the equivalent plutonic rock names. Fields of alkalinity modified slightly from those in DeWitt (1989) based on Ed DeWitt (unpub. data, 1994).

(B) Alumina saturation diagram $\left(\mathrm{SiO}_{2}\right.$ versus $\left.\mathrm{A} / \mathrm{CNK}\right)$. $\mathrm{A}$, molar $\mathrm{Al}_{2} \mathrm{O}_{3} ; \mathrm{C}$, molar $\mathrm{CaO} ; \mathrm{N}$, molar $\mathrm{Na}_{2} \mathrm{O} ; \mathrm{K}$, molar $\mathrm{K}_{2} \mathrm{O}$.

(C) Alkali classification diagram $\left(\mathrm{K}_{2} \mathrm{O} /\left(\mathrm{K}_{2} \mathrm{O}+\mathrm{Na}_{2} \mathrm{O}\right)\right.$ versus $\left.\mathrm{SiO}_{2}\right)$. Field boundaries from Ed DeWitt (unpub data, 1994).

(D) Iron enrichment classification diagram $\left(\left(\mathrm{FeO}+0.89 * \mathrm{Fe}_{2} \mathrm{O}_{3}\right) /\left(\mathrm{FeO}+0.89 * \mathrm{Fe}_{2} \mathrm{O}_{3}+\mathrm{MgO}\right)\right.$ versus $\left.\mathrm{SiO}_{2}\right)$. Field boundaries slightly modified from those in DeWitt (1989) based on Ed DeWitt (unpub. data, 1994).

Red Mountain, west of Bowman Creek, and east of Tellurium Lake (Perkins, 1973). Stocks are typically porphyritic-aphanitic and strongly altered. Stocks are spatially coincident with zones of strong hydrothermal alteration and weak mineralization resembling that of porphyry molybdenum deposits.

Composition inferred from relict phenocrysts and phenocryst pseudomorphs to be generally granodioritic in composition. No chemical analyses available for the stocks.

Oligocene age assignment based on $\mathrm{K}-\mathrm{Ar}$ dates from one stock. The stock on Pine Creek has $\mathrm{K}$-Ar biotite dates of $35.7 \pm 1.2 \mathrm{Ma}$ and 36.8 $\pm 1,4 \mathrm{Ma}$ (original Kennecott data recalculated by Fridrich and others, 1991, using decay constants of Steiger and Jäger, 1977). Although these dates are older than the dates on the oldest resurgent plutons, we consider these plutons to be younger. The original geochronologic data for the age calculations are lacking and we suspect that the material dated may not have been free of impurities, especially clay minerals that could contain excess argon. The stocks are presumed to have been emplaced late in the resurgence of the caldera because they coincide with ring fracture zones that were reactivated during caldera resurgence 
Oldest resurgent plutons-The Lincoln Gulch stock, named by Candee (1971) and described by Fridrich and Mahood (1984), is a composite laccolith consisting of three intrusive bodies, as described below. All three bodies are porphyritic-aphanitic throughout (both phenocrysts and groundmasses become coarser toward the cores) and contain locally abundant inclusions (to $1 \mathrm{~m}$ diameter) of Early Proterozoic metasedimentary gneiss (unit $\mathrm{Xgn}$ ) and lati-andesite porphyry. Includes several related dikes found both within and outside of the composite laccolith

Youngest pluton (Oligocene)-Concentrically zoned from leucocratic granodiorite margins to a more mafic granodiorite core. Largest body is exposed on high ridge, north of Grizzly Peak. Margins are medium pinkish tan to tan gray; core is medium greenish gray. Margin contains about $45 \%$ phenocrysts of plagioclase, quartz, alkali feldspar, biotite, and less abundant magnetite. Core contains about $60 \%$ phenocrysts of abundant plagioclase and biotite, lesser amounts of quartz and alkali feldspar, and sparse magnetite

Intermediate-age pluton (Oligocene)Concentrically zoned from leucocratic granodiorite margins to a tonalite core. Exposed from mouth of Tabor Creek on the northwest, nearly to Grizzly Peak on the southeast. Margins are dark grayish green to medium greenish gray; core is medium salt-and-pepper gray. Margins have about 35\% phenocrysts of abundant plagioclase, quartz, and biotite, and lesser alkali feldspar and magnetite. Core contains about $55 \%$ phenocrysts of abundant plagioclase and biotite, and lesser quartz, hornblende, magnetite, and alkali feldspar.

Oligocene age assignment for all three bodies is based on $\mathrm{K}$-Ar biotite date of 34.8 $\pm 1.1 \mathrm{Ma}$ (recalculated from data in Obradovich and others, 1969, by Fridrich and others, 1991) for unit Tr2

Oldest pluton (Oligocene)-Concentrically zoned from leucocratic granodiorite margins to a tonalite core. Exposed from mouth of Tabor Creek on the northwest, to near Grizzly Peak on the southeast. Margins are light bluish or yellowish gray; core is medium salt-and-pepper gray. Margins contain about $30 \%$ phenocrysts of abundant plagioclase, quartz, alkali feldspar, and biotite, and lesser amounts of magnetite. Core contains about $60 \%$ phenocrysts of abundant plagioclase, biotite, and quartz, lesser magnetite and alkali feldspar, and minor hornblende. Also includes a ring dike that is well exposed at East Red and along southeastern margin of the caldera.

All three plutons range in composition from granodiorite to tonalite, are alkali-calcic (fig. 3A), mildly peraluminous (fig. 3B), have no preferential alkali enrichment (fig. 3C), and are average to slightly $\mathrm{Mg}$ rich (fig. 3D). The slope of data points on the alumina saturation diagram is surprisingly low. Most igneous rocks having less than $60 \% \mathrm{SiO}_{2}$ are normally metaluminous. The plutons bear a strong chemical similarity to the Italian Mountain intrusive complex (unit Tim)

\section{Grizzly Peak Tuff}

A phenocryst-rich (20-40\%) lithic lapilli ash-flow tuff (Fridrich and others, 1991) that varies in composition from high- to low-silica rhyolite (about $77-71 \% \mathrm{SiO}_{2}$ ). Two horizons are noted that contain as much as $20 \%$ subrhyolitic $\left(66-57 \% \mathrm{SiO}_{2}\right)$ fiamme (collapsed pumice lumps) in addition to the rhyolitic fiamme and ash found in the rest of the tuff. Predominant lithic fragments are Early Proterozoic metasedimentary gneiss (unit $\mathrm{Xgn}$ ), St. Kevin Granite (unit Ys), Denny Creek Granodiorite (unit $\mathrm{Xd}$ ), and a high-silica rhyolite porphyry resembling the precaldera rhyolite lava (unit Tf). Grizzly Peak Tuff is subdivided everywhere into four compositional subunits; no unit-wide cooling breaks are present between subunits. The distinction between subunits is arbitrary and is based on composition and on the positions of two very thick megabreccias in the caldera fill. Local cooling breaks formed as chilled margins around breccias intercalated in the tuff.

Intracaldera tuff has biotite and hornblende $\mathrm{K}$-Ar dates of $33.4 \pm 1.0 \mathrm{Ma}$ and $33.8 \pm 1.1$ Ma, respectively (Fridrich and others, 1991)

Tgh2 Upper heterogeneous subunit (Oligocene)Heterogeneous tuff layer containing larger and more mafic fiamme than rest of Grizzly Peak Tuff. Layer caps the upper rhyolite subunit (Tgu). Exposed only on high ridge at head of Mountain Boy Gulch. Subunit has a thickness of $40 \mathrm{~m}$, is medium rusty red (or black where vitrophyric) and contains fiamme that have the identical range of compositions, but different colors, than those in the lower heterogeneous tuff layer (unit Tghl). Matrix of layer is a low-silica rhyolite, similar in composition to the immediately underlying 
tuff (unit Tgu). Fiamme in the layer range in color from white to very light bluish gray for high- to low-silica rhyolite, medium rusty red for dacite, and dark rust for lati-andesite containing phenocrysts of biotite-hornblendeorthopyroxene or hornblende-orthopyroxenebiotite

Tgu Upper rhyolite subunit (Oligocene)-Rhyolite tuff containing numerous intercalated wedges, sheets, and tongues of megabreccia, as well as layers strewn with giant, internally shattered boulders. Preserved only in the northeastern part of the caldera, where it overlies a $>300$-m-thick layer of caldera-collapse megabreccia (unit $\mathrm{Tm}$ ). Typically medium brown, orange brown, or reddish brown; very lithic rich and contains lithics predominantly of Early Proterozoic gneiss (unit Xgn), St. Kevin Granite (unit Ys), Denny Creek Granodiorite (unit Xd), and granodiorite of Sayers (unit YXs). Thickness about about $400 \mathrm{~m}$. Contains about $35 \%$ phenocrysts of plagioclase, quartz, alkali feldspar, biotite, and magnetite, and trace amounts of zircon, apatite, and monazite. Biotite and magnetite are about twice as abundant as in the medium- silica rhyolite (unit Tgm).

Composition is low-silica, ranging from about 70 to $72.5 \% \mathrm{SiO}_{2}$. Low-silica rhyolitic fiamme are alkali-calcic (fig. 3A), mildly to strongly peraluminous (fig. 3B), have a slight sodic enrichment (fig. 3C), and no significant iron enrichment (fig. 3D). Other, more mafic fiamme have a range in composition, from as mafic as calc-alkalic lati-andesite and calc-alkalic quartz latite to calc-alkalic rhyodacite (fig. 3A). These mafic fiamme are metaluminous (fig. 3B) and have little apparent alkali or iron enrichment (figs. 3C and D). Quartz latite fiamme are enriched in Th and are commonly sodic, suggesting that they are not the product of alteration but instead may represent a distinctly more alkalic magma than the bulk of the Grizzly Peak Tuff represents.

Sample of outflow tuff south of Twin Lakes Reservoir and west of Granite that is probably equivalent to the upper rhyolite subunit has a $\mathrm{K}$-Ar biotite date of $33.3 \pm 1.0$ Ma

Tgh1 Lower heterogeneous subunit (Oligocene)Heterogeneous tuff layer containing larger and more mafic fiamme than rest of Grizzly Peak Tuff. Layer caps the middle rhyolite subunit (Tgm). Exposed at Garfield Peak and on slope west of Ruby. Subunit is $\geq 50 \mathrm{~m}$ thick, is medium to dark gray, has a medium-silica rhyolite matrix, and contains fiamme ranging in color from bluish white for high-silica rhyolite, light gray for mediumand low-silica rhyolite, medium gray for dacite, and black for lati-andesite containing phenocrysts of biotite-hornblende-orthopyroxene and hornblende- orthopyroxene-biotite. All of the non-rhyolitic fiamme have about $40 \%$ phenocrysts

Tgm Middle rhyolite subunit (Oligocene)-Darkcharcoal-gray, dark-reddish-brown, and medium-lavender-gray tuff. Welding varies but predominantly is dense. Groundmass crystallinity increasingly granophyric (with feldspars phenocrysts over $1 \mathrm{~mm}$ in long dimension) toward the center of the caldera. Extensively exposed on western side of caldera. Interbedded with megabreccia on eastern side of caldera. Where granophyrically crystallized, subunit is dark and pyroclastic textures are difficult to discern. Thickness ranges from about 250 to $600 \mathrm{~m}$. Subunit typically has about $30 \%$ phenocrysts of plagioclase, quartz, alkali feldspar, biotite, and magnetite, in decreasing concentrations. Biotite and magnetite are more than twice as abundant as in the high-silica lower rhyolite subunit, Tgl). Contains trace amounts of zircon, apatite, monazite, and allanite.

Composition is medium-silica rhyolite, ranging from about 72.5 to $75 \% \quad \mathrm{SiO}_{2}$. Medium-silica rhyolite fiamme are similar in composition to low-silica rhyolite fiamme, but some are metaluminous at $\mathrm{SiO}_{2}$ concentrations of more than $72 \%$ (fig. 3B), indicating that they are hydrothermally altered. Some of these altered fiamme are also notably sodic (fig. 3C)

Tgl Lower rhyolite subunit (Oligocene)-White, gray, light-yellow, light- to medium-red, tan, lavender, or black (where vitrophyric) rhyolite tuff. The predominant lithic is the precaldera rhyolite lava (unit Tf). Exposed extensively around the north, west, and south margins of the caldera. At base, the tuff is a nearly monolithologic tuff breccia. Welding varies from predominantly dense to poor. Thickness ranges from about 0.5 to $1.0 \mathrm{~km}$. Contains about $20 \%$ phenocrysts of quartz, sanidine, and plagioclase in subequal amounts, minor biotite, and traces of monazite, allanite, zircon, and apatite. 
Composition is high-silica rhyolite, ranging from about 75 to $77 \% \mathrm{SiO}_{2}$. No chemical data are available for most of the high-silica rhyolite

\section{Caldera-Collapse Breccia}

Extremely coarse rock-avalanche breccia forming wedges, sheets, and tongues intercalated within the intracaldera Grizzly Peak Tuff. Most clasts longer than $1 \mathrm{~m}$ are internally shattered. Composed dominantly of clasts of Early Proterozoic Denny Creek Granodiorite (unit Xd), St. Kevin Granite (unit $Y s$ ), metasedimentary gneiss (unit $X m s$ ), and granodiorite of Sayers (unit YXs) which formed the wallrocks of the Grizzly Peak caldera. Less common constituents include intrusive rocks of the Twin Lakes Pluton (units $\mathrm{Tt}, \mathrm{Ttl}$, and $\mathrm{Ttm}$ ) and precaldera rhyolite (unit Tf). Everywhere divided into the following three subunits

Tm Megabreccia (Oligocene)-Caldera-collapse breccias containing little or no tuff matrix. Typical clast size is tens of meters long; maximum clast size is at least $0.5 \mathrm{~km}$ long. Minor seams of tuff matrix are present between some giant clasts. Exposed extensively in eastern and northeastern part of caldera

Tmt Clast-supported tuff megabreccia (Oligocene)-Caldera-collapse breccia, but typical clast size is smaller and has an average length of $<10 \mathrm{~m}$ and a maximum length of about $50 \mathrm{~m}$. Exposed between East Red and Grizzly Peak. Large masses of tuff matrix surround the shattered giant clasts. Most tuff matrix is nonwelded or poorly welded, but large masses show increased welding inward. Composition of the tuff matrix is similar to that of either underlying or overlying tuff

Ttm Matrix-supported tuff megabreccia (Oligocene)-Caldera-collapse breccia, similar to tuff megabreccia (unit Tmt), but clasts are matrix supported, are typically well rounded, and most range between 2 and $10 \mathrm{~m}$ in diameter. Clasts composed dominantly of Denny Creek Granodiorite (unit Xd), Twin Lakes Pluton (units Tt, Ttl, and Ttm), and St. Kevin Granite (unit Ys). Matrix is poorly welded, lithic rich, low-silica rhyolite unit of the Grizzly Peak Tuff. Exposed in a single area in the northeast part of the caldera, at the head of Negro Gulch
Precaldera rhyolite lava (Oligocene)Grayish white or pink high-silica rhyolite lava and porphyry. Exposed southeast of the head of Tellurium Creek. Crops out as a flow beneath the Grizzly Peak Tuff and as a small stock of porphyry which underlies the flow. Closely resembles the first-erupted high-silica rhyolite of the overlying Grizzly Peak Tuff (unit Tgl) in chemistry and phenocryst assemblage

Tw Intrusive rocks of the White Rock pluton (Oligocene)-Light-gray, medium- to finegrained, equigranular, biotite-hornblende granodiorite and associated rocks. Forms White Rock pluton or laccolithic intrusive complex, 15 by $15 \mathrm{~km}$ in extent, that intrudes Paleozoic and Mesozoic strata in the far western part of the map area (Bryant, 1979). Some small dikes and sills associated with pluton not shown at scale of map. Main rock type is granodiorite, which consists, in decreasing amounts, of oligoclase to andesine, quartz, potassic feldspar, biotite, opaque minerals, hornblende, and minor amounts of apatite, zircon, sphene, and allanite.

The main pluton ranges from tonalite to granodiorite, straddles the border between alkali-calcic and calc-alkalic (fig. 4A), ranges from metaluminous to mildly peraluminous (fig. 4B), and shows no strong alkali enrichment or iron enrichment trends (fig. 4C, D). Rocks as mafic as gabbro-diorite to diorite are associated with the granodiorite, but constitute a minor percentage of the pluton. Dikes are predominately granodiorite in composition. No minor element geochemistry is available.

Oligocene age assignment based on $\mathrm{K}-\mathrm{Ar}$ biotite date of $34.8 \pm 1.0 \mathrm{Ma}$ from sample to west of map area, as recalculated by Wallace (1993) from data in Obradovich and others (1969)

Tim Intrusive rocks of the Italian Mountain intrusive complex (Oligocene)-Medium- to dark-gray, medium-grained, equigranular quartz diorite to light-gray, fine-grained, porphyritic dacite. Exposed in far southwestern part of map area. Cunningham (1976) identified three intrusive centers which are not separated on this map. Intrudes rocks as young as the Pennsylvanian Belden Formation. Quartz diorite consists, in decreasing amounts, of plagioclase, quartz, potassium feldspar, hornblende, biotite, epidote, opaque minerals, and minor amounts of sphene, apatite, and zircon. Rocks of intermediate composition (described by Cunningham (1976) as granodiorite and quartz monzonite) have less 


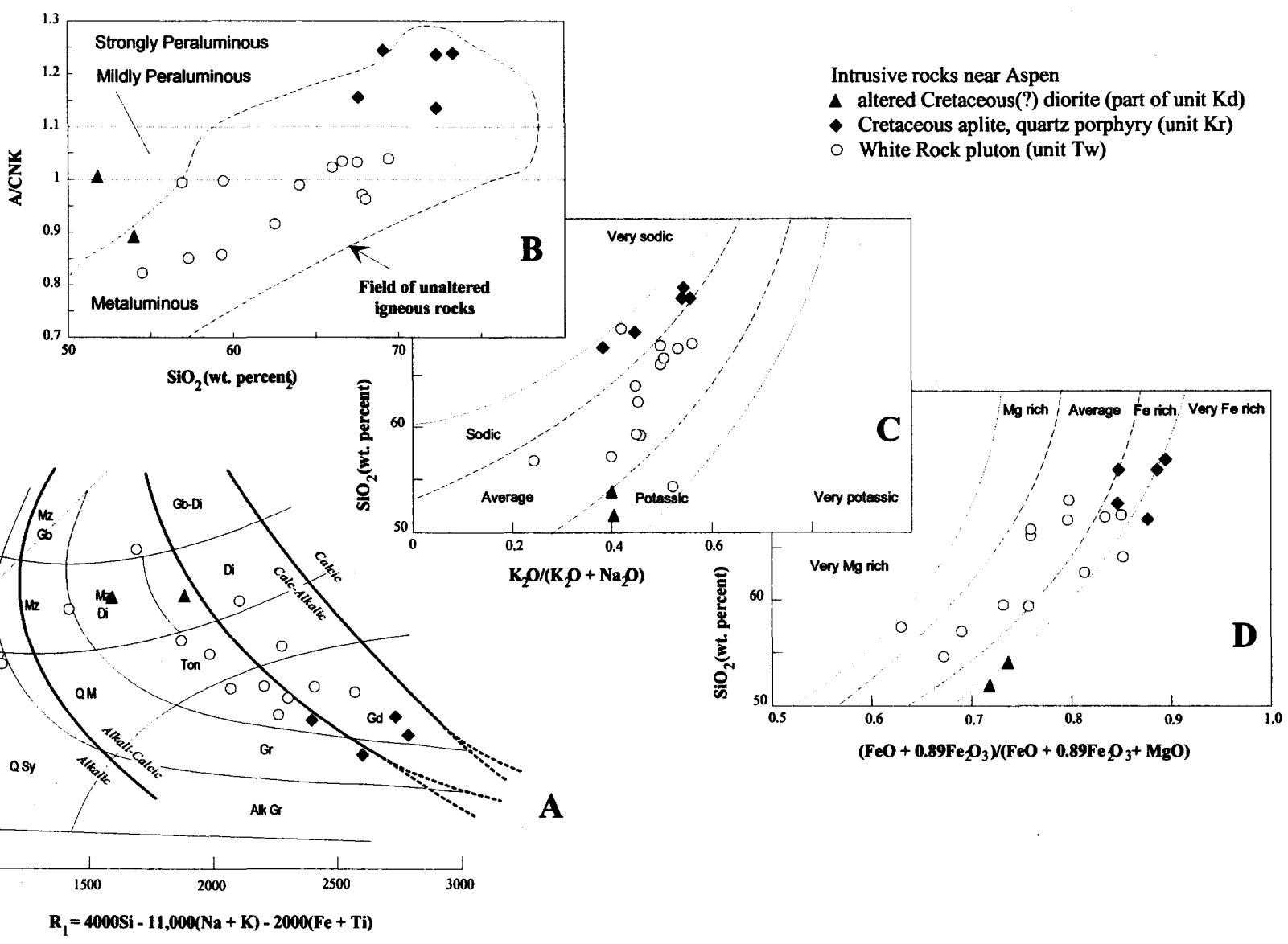

Figure 4. Summary geochemical diagrams for Cretaceous and Tertiary intrusive rocks in the Aspen area. Data from Bruce Bryant (1979; unpub. data, 1994).

(A) $R_{1} R_{2}$ major element classification diagram (De la Roche and others, 1980). Alk Gr, alkali granite; Gr, granite; Gd, granodiorite; Ton, tonalite; $\mathrm{Di}$, diorite; Gb-Di, gabbro-diorite; $\mathrm{Mz} \mathrm{Gb}$, monzogabbro; $\mathrm{Mz}$ Di, monzodiorite; $\mathrm{Q} \mathrm{M}$, quartz monzonite; Q Sy, quartz syenite; Sye, syenite; Sy Di, syenodiorite; Sy Gb, syenogabbro. Fields of alkalinity modified slightly from those in DeWitt (1989) based on Ed DeWitt (unpub. data, 1994).

(B) Alumina saturation diagram $\left(\mathrm{SiO}_{2}\right.$ versus $\left.\mathrm{A} / \mathrm{CNK}\right)$. $\mathrm{A}$, molar $\mathrm{Al}_{2} \mathrm{O}_{3} ; \mathrm{C}$, molar $\mathrm{CaO} ; \mathrm{N}$, molar $\mathrm{Na}_{2} \mathrm{O} ; \mathrm{K}$, molar $\mathrm{K}_{2} 0$.

(C) Alkali classification diagram $\left(\mathrm{K}_{2} \mathrm{O} /\left(\mathrm{K}_{2} \mathrm{O}+\mathrm{Na}_{2} \mathrm{O}\right)\right.$ versus $\left.\mathrm{SiO}_{2}\right)$. Field boundaries from Ed DeWitt (unpub data, 1994).

(D) Iron enrichment classification diagram $\left(\left(\mathrm{FeO}+0.89 * \mathrm{Fe}_{2} \mathrm{O}_{3}\right) /\left(\mathrm{FeO}+0.89 * \mathrm{Fe}_{2} \mathrm{O}_{3}+\mathrm{MgO}\right)\right.$ versus $\left.\mathrm{SiO}_{2}\right)$. Field boundaries slightly modified from those in DeWitt (1989) based on Ed DeWitt (unpub. data, 1994).

plagioclase and hornblende, more quartz, potassium feldspar, and biotite, and lower concentrations of opaque minerals. Late dikes and vent-facies rocks are porphyritic and have a fine-grained groundmass. Includes large east-striking dike west of Italian Mountain.

The suite ranges in composition from tonalite to granite (fig. 5A) and is metaluminous (tonalite and vent-facies rocks) to strongly peraluminous (fig. 5B). A large range in alkali enrichment is noted, from very sodic tonalite and granodiorite to average granodiorite (fig. 5C), although most of the suite has no preferential alkali enrichment. The suite varies from very $\mathrm{Mg}$ rich to very $\mathrm{Fe}$ rich (fig. 5D) Some late dikes are very $\mathrm{Mg}$ rich. These wide ranges in $\mathrm{Fe}$ enrichment and alkali enrichment distinguish these intrusive rocks from other Oligocene rocks in the area. In terms of major-element composition, the bulk of the Italian Mountain intrusive complex closely resembles the resurgent plutons (Lincoln Gulch Stock) of the Grizzly Peak caldera.

Oligocene age assignment based on fission-track zircon date of $33.9 \pm 3.9 \mathrm{Ma}$ from porphyritic granodiorite, the youngest rock in 


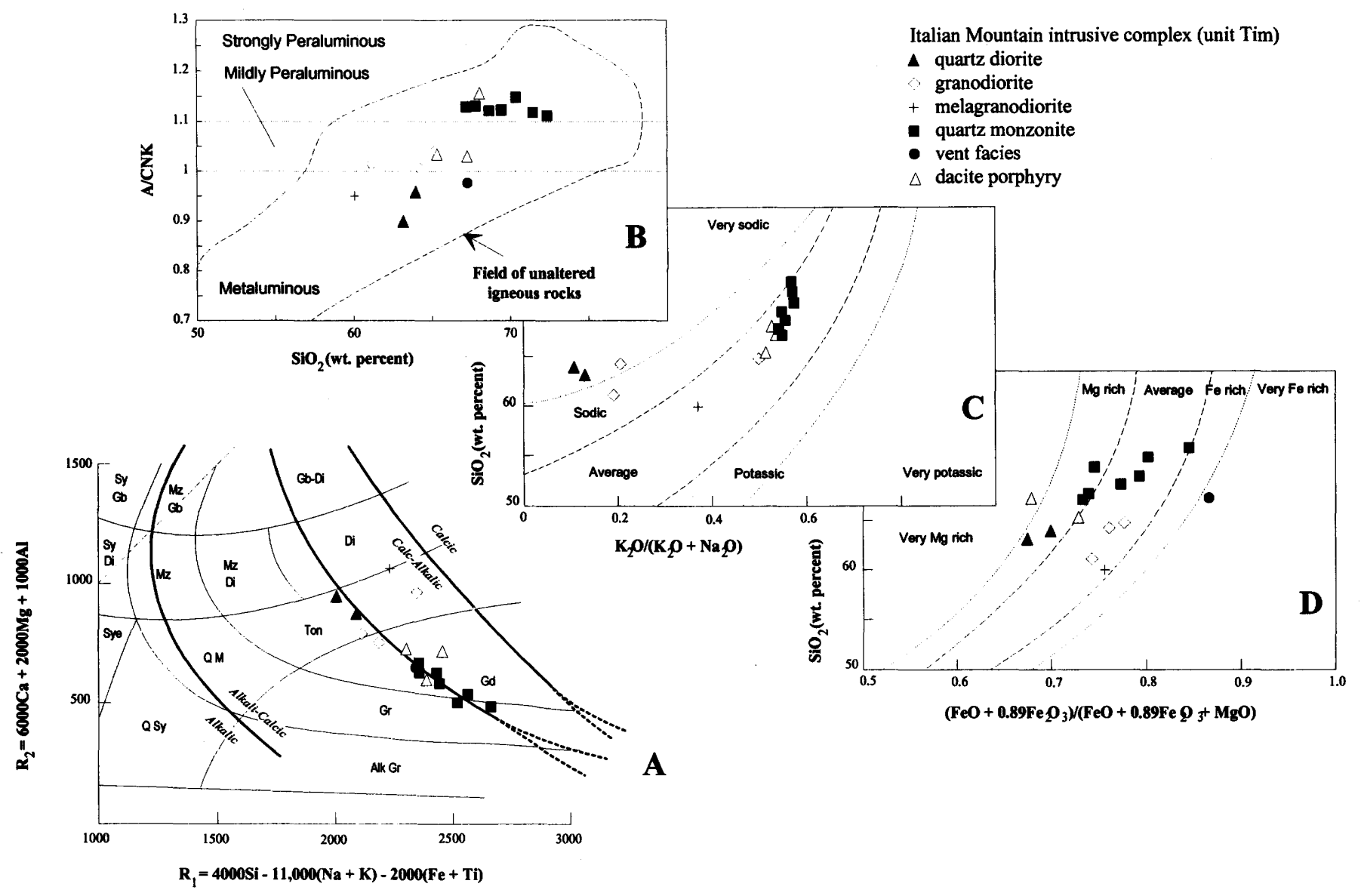

Figure 5. Summary geochemical diagrams for the Italian Mountain intrusive complex. Data and rock names from Cunningham (1976)

(A) $R_{1} R_{2}$ major element classification diagram (De la Roche and others, 1980). Alk Gr, alkali granite; Gr, granite; Gd, granodiorite; Ton, tonalite; $\mathrm{Di}$, diorite; $\mathrm{Gb}-\mathrm{Di}$, gabbro-diorite; $\mathrm{Mz} \mathrm{Gb}$, monzogabbro; $\mathrm{Mz} \mathrm{Di}$, monzodiorite; $\mathrm{Q} \mathrm{M}$, quartz monzonite; Q Sy, quartz syenite; Sye, syenite; Sy Di, syenodiorite; Sy Gb, syenogabbro. Fields of alkalinity modified slightly from those in DeWitt (1989) based on Ed DeWitt (unpub. data, 1994).

(B) Alumina saturation diagram $\left(\mathrm{SiO}_{2}\right.$ versus $\left.\mathrm{A} / \mathrm{CNK}\right)$. A, molar $\mathrm{Al}_{2} \mathrm{O}_{3} ; \mathrm{C}$, molar $\mathrm{CaO} ; \mathrm{N}$, molar $\mathrm{Na}_{2} \mathrm{O} ; \mathrm{K}$, molar $\mathrm{K}_{2} 0$.

(C) Alkali classification diagram $\left(\mathrm{K}_{2} \mathrm{O} /\left(\mathrm{K}_{2} \mathrm{O}+\mathrm{Na}_{2} \mathrm{O}\right)\right.$ versus $\left.\mathrm{SiO}_{2}\right)$. Field boundaries from $\mathrm{Ed} \mathrm{DeWitt}$ (unpub data, 1994).

(D) Iron enrichment classification diagram $\left(\left(\mathrm{FeO}+0.89 * \mathrm{Fe}_{2} \mathrm{O}_{3}\right) /\left(\mathrm{FeO}+0.89 * \mathrm{Fe}_{2} \mathrm{O}_{3}+\mathrm{MgO}\right)\right.$ versus $\left.\mathrm{SiO}_{2}\right)$. Field boundaries slightly modified from those in DeWitt (1989) based on Ed DeWitt (unpub. data, 1994).

the intrusive sequence (recalculated from Cunningham and Naeser, 1975, by Cunningham and others, 1995)

Twf Felsic plutons and dikes of Winfield Peak and Middle Mountain (Eocene)-Light-gray, tan, and white, very fine-grained, porphyritic rhyolite, rhyolite porphyry, and granite plugs and dikes, and areas of hydrothermally altered rocks, breccia, and minor pegmatite (Ranta, 1974; Gunow, 1983). Intrusive rocks and breccia have molybdenum prospects and minor gold-silver prospects. Granite and hypabyssal rocks restricted to area of Winfield Peak and Middle Mountain. Rhyolite and rhyolite porphyry dikes widespread in eastern half of map area, from Mount Elbert to Mount Columbia. Also includes stock east of Mount Champion (Van Loenen and others, 1989). Rhyolite, rhyolite porphyry, and felsic dikes consist of fine-grained groundmass of quartz and potassium feldspar and 5-15\% phenocrysts of euhedral quartz, perthitic sanidine, albite, and minor biotite. Granite consists of orthoclase, quartz, plagioclase, biotite, and minor amounts of magnetite, apatite, zircon, muscovite, fluorite, and molybdenite.

Although most of the rocks at Winfield are hydrothermally altered to varying degrees, rhyolite and granite appear to have been 
alkali-calcic (fig. 6A), mildly peraluminous (fig. 6B), sodic (fig. 6C), and have no major iron enrichment (fig. 6D). Similar rocks east of Mount Champion have approximately the same major element composition (fig. 7a), but are markedly peraluminous because of their extensive conversion to clay minerals (such rocks plot off scale of fig. 7B), and are very potassic because of their secondary potassium feldspar (fig. 7C).

Minor-element chemistry distinguishes these felsic rocks from other suites of felsic rocks related to the Grizzly Peak caldera or to Cretaceous plutonism. Least-altered rhyolite is characterized by low concentrations of $\mathrm{Zr}$
$(<50 \mathrm{ppm})$ and high concentrations of $\mathrm{Nb}$ $(>40 \mathrm{ppm})$. Distinguished from resurgent intrusive dikes and stocks of the Grizzly Peak caldera and from Cretaceous rhyolite (unit $\mathrm{Kr}$ ) by low concentrations of $\mathrm{Zr}$, $\mathrm{Sr}$, and high concentrations of $\mathrm{Nb}$. Dikes for which chemical analyses indicate certainty in classification are indicated on map with small box on dike symbol. Dikes that lack chemical samples but that are inferred to belong to this unit on the basis of petrography are indicated by no box on the dike symbol.

Eocene age assignment based on $\mathrm{K}$-Ar biotite date of $38.8 \pm 1.3 \mathrm{Ma}$ from the Middle Mountain porphyry, one of the oldest rocks at

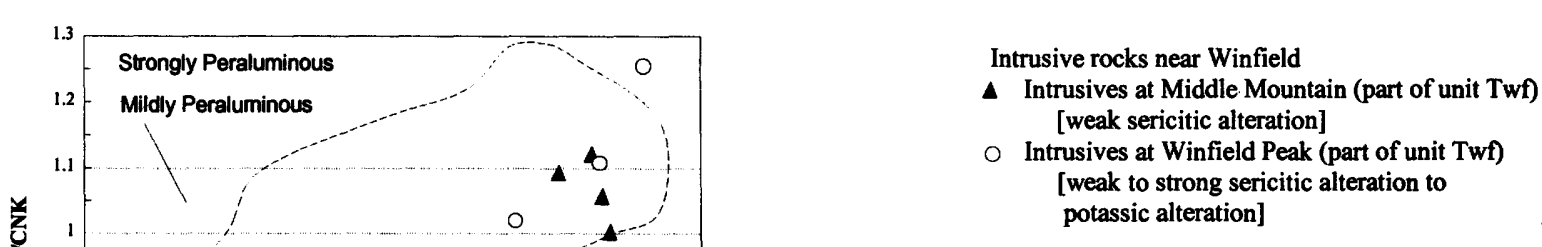

Intrusive rocks near Winfield weak to strong sericitic alteration to potassic alteration]
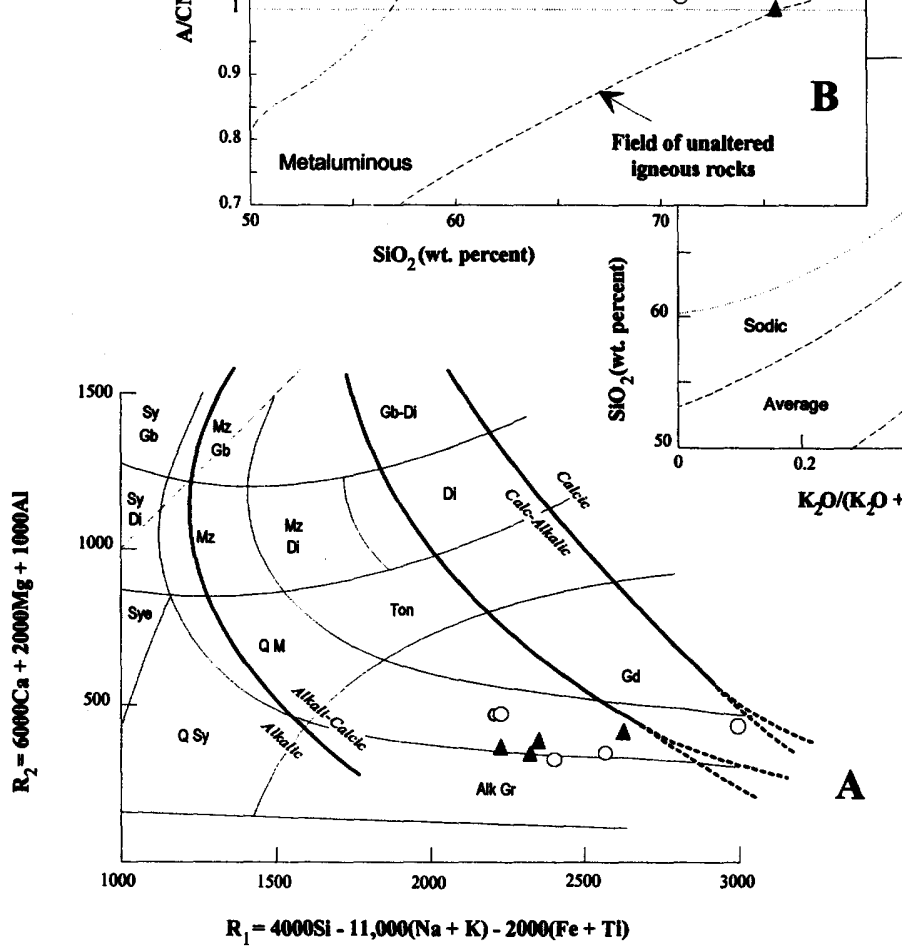

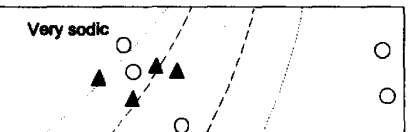

$\Delta$

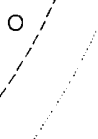

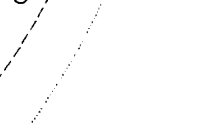

Figure 6. Summary geochemical diagrams for altered intrusive rock at Middle Mountain and Winfield Peak. Data from Gunow (1983) and Ranta (1974).

(A) $R_{1} R_{2}$ major element classification diagram (De la Roche and others, 1980). Alk Gr, alkali granite; Gr, granite; Gd, granodiorite; Ton, tonalite; $\mathrm{Di}$, diorite; Gb-Di, gabbro-diorite; $\mathrm{Mz} \mathrm{Gb}$, monzogabbro; $\mathrm{Mz} \mathrm{Di}$, monzodiorite; $\mathrm{Q} \mathrm{M}$, quartz monzonite; Q Sy, quartz syenite; Sye, syenite; Sy Di, syenodiorite; Sy Gb, syenogabbro. Fields of alkalinity modified slightly from those in DeWitt (1989) based on Ed DeWitt (unpub. data, 1994).

(B) Alumina saturation diagram $\left(\mathrm{SiO}_{2}\right.$ versus $\left.\mathrm{A} / \mathrm{CNK}\right)$. $\mathrm{A}$, molar $\mathrm{Al}_{2} \mathrm{O}_{3} ; \mathrm{C}$, molar $\mathrm{CaO} ; \mathrm{N}$, molar $\mathrm{Na}_{2} \mathrm{O} ; \mathrm{K}$, molar $\mathrm{K}_{2} 0$.

(C) Alkali classification diagram $\left(\mathrm{K}_{2} \mathrm{O} /\left(\mathrm{K}_{2} \mathrm{O}+\mathrm{Na}_{2} \mathrm{O}\right)\right.$ versus $\left.\mathrm{SiO}_{2}\right)$. Field boundaries from Ed DeWitt (unpub data, 1994).

(D) Iron enrichment classification diagram $\left(\left(\mathrm{FeO}+0.89 * \mathrm{Fe}_{2} \mathrm{O}_{3}\right) /\left(\mathrm{FeO}+0.89 * \mathrm{Fe}_{2} \mathrm{O}_{3}+\mathrm{MgO}\right)\right.$ versus $\left.\mathrm{SiO}_{2}\right)$. Field boundaries slightly modified from those in DeWitt (1989) based on Ed DeWitt (unpub. data, 1994). 


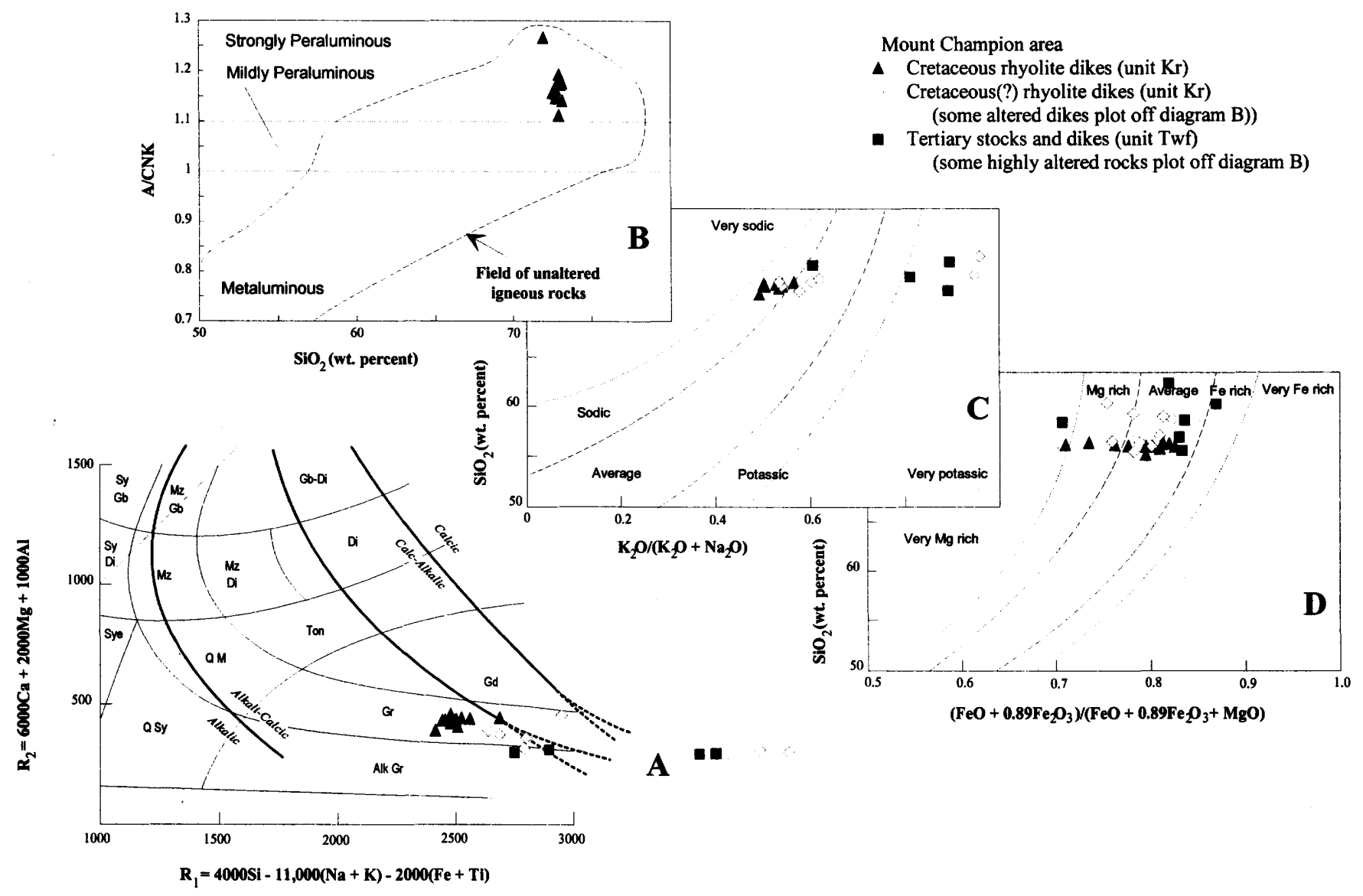

Figure 7. Summary geochemical diagrams for rocks of the Mount Champion area. Data from R.E. Van Loenen (1989; unpub. data, 1994).

(A) $R_{1} R_{2}$ major element classification diagram (De la Roche and others, 1980). Alk Gr, alkali granite; Gr, granite; Gd, granodiorite; Ton, tonalite; Di, diorite; Gb-Di, gabbro-diorite; Mz Gb, monzogabbro; Mz Di, monzodiorite; Q M, quartz monzonite; Q Sy, quartz syenite; Sye, syenite; Sy Di, syenodiorite; Sy Gb, syenogabbro. Fields of alkalinity modified slightly from those in DeWitt (1989) based on Ed DeWitt (unpub. data, 1994).

(B) Alumina saturation diagram $\left(\mathrm{SiO}_{2}\right.$ versus $\left.\mathrm{A} / \mathrm{CNK}\right)$. A, molar $\mathrm{Al}_{2} \mathrm{O}_{3} ; \mathrm{C}$, molar $\mathrm{CaO} ; \mathrm{N}$, molar $\mathrm{Na}_{2} \mathrm{O} ; \mathrm{K}$, molar $\mathrm{K}_{2} \mathrm{O}$.

(C) Alkali classification diagram $\left(\mathrm{K}_{2} \mathrm{O} /\left(\mathrm{K}_{2} \mathrm{O}+\mathrm{Na}_{2} \mathrm{O}\right)\right.$ versus $\left.\mathrm{SiO}_{2}\right)$. Field boundaries from Ed DeWitt (unpub data, 1994).

(D) Iron enrichment classification diagram $\left(\left(\mathrm{FeO}+0.89 * \mathrm{Fe}_{2} \mathrm{O}_{3}\right) /\left(\mathrm{FeO}+0.89 * \mathrm{Fe}_{2} \mathrm{O}_{3}+\mathrm{MgO}\right)\right.$ versus $\left.\mathrm{SiO}_{2}\right)$. Field boundaries slightly modified from those in DeWitt (1989) based on Ed DeWitt (unpub. data, 1994).

Winfield, and $\mathrm{K}-\mathrm{Ar}$ biotite date of $37.7 \pm 1.2$ Ma from the granite, one of the youngest rocks at Winfield (dates recalculated from data in Ranta, 1974)

Tmp Intrusive rocks of the Mount Princeton pluton (Eocene)-Light-tan to greenish-tan, medium-grained, equigranular to slightly porphyritic tonalite to granodiorite and aplite. Exposed southwest and east of Mount Yale. Forms large pluton south of map area (Dings and Robinson, 1957; Shannon, 1988; Toulmin and Hammarstrom, 1990). Rock types exposed in map area restricted to granodiorite and aplite. Includes Mount Princeton Quartz Monzonite and Mount Pomeroy Quartz
Monzonite (Dings and Robinson, 1957), the latter of which is interpreted as border facies of the pluton. The border consists, in decreasing amounts, of plagioclase, potassium feldspar, hornblende and biotite, quartz, opaque minerals, and minor amounts of sphene, zircon, and allanite. Main body (granodiorite) consists of characteristically turbid, normal and oscillatory zoned oligoclase, slightly turbid to clear microcline and perthite, quartz, actinolitic hornblende, biotite, magnetite, ilmenite, apatite, zircon, and sphene. Aplite contains traces of muscovite in association with biotite, but no hornblende. 
Most of the intrusive rocks range from tonalite to granodiorite (fig. 8A). Tonalite (not exposed in map area), is alkali-calcic (fig. 8A), metaluminous (fig. 8B), average to slightly potassic (fig. 8C), and average to $\mathrm{Mg}$ rich (fig. 8D). Granodiorite is alkali-calcic to calc-alkalic (fig. 8A), metaluminous to mildly peraluminous (fig. 8B), and average to $\mathrm{Mg}$ rich (fig. 8D). Features that distinguish the Mount Princeton pluton from other intrusive rocks in the area are its highly alkali-calcic chemistry and $\mathrm{Mg}$-rich character.

Eocene age assignment based on unpublished fission-track and U-Th- $\mathrm{Pb}$ dates and published ${ }^{40} \mathrm{Ar}-{ }^{39} \mathrm{Ar}$ dates from samples south of the map area. Fission-track dates from sphene as old as 39.4 to $41.2 \pm 3.2 \mathrm{Ma}$ and zircon as old as $36.6 \pm 0.4 \mathrm{Ma}$ suggest the pluton is Eocene (Shannon, 1988). A minus400-mesh zircon fraction from a sample along Chalk Creek, south of Mount Princeton, has a ${ }^{208} \mathrm{~Pb} /{ }^{232} \mathrm{Th}$ date of $36.6 \mathrm{Ma}$. If an upper intercept date of $1700 \mathrm{Ma}$ is assumed for the zircon, a lower intercept date of $36.6 \pm 0.4 \mathrm{Ma}$ is obtained (E. DeWitt and R.E. Zartman, unpub. data, 1990). Two ${ }^{40} \mathrm{Ar}-{ }^{39} \mathrm{Ar}$ hornblende dates of $36.3 \pm 0.3 \mathrm{Ma}$ and $37.1 \pm 0.3$ $\mathrm{Ma}$ from the pluton also suggest a latest Eocene age (Toulmin and Hammarstrom, 1990)

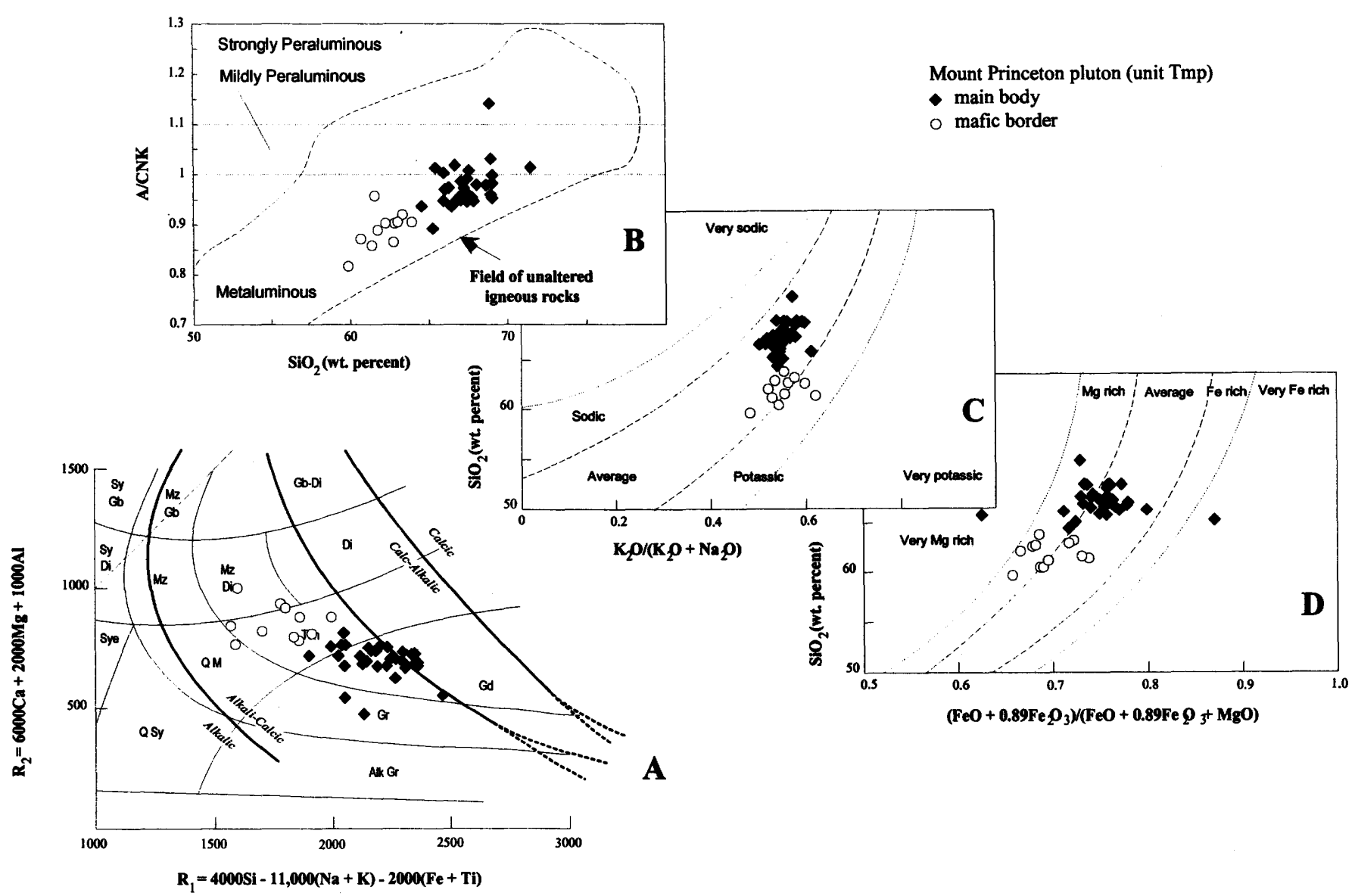

Figure 8. Summary geochemical diagrams for intrusive rocks of the Mount Princeton Pluton. Data from J.R. Shannon (1988; unpub. data, 1994) and Ed DeWitt (unpub. data, 1994).

(A) $R_{1} R_{2}$ major element classification diagram (De la Roche and others, 1980). Alk Gr, alkali granite; Gr, granite; Gd, granodiorite; Ton, tonalite; $\mathrm{Di}$, diorite; Gb-Di, gabbro-diorite; $\mathrm{Mz} \mathrm{Gb}$, monzogabbro; $\mathrm{Mz} \mathrm{Di}$, monzodiorite; $\mathrm{Q} \mathrm{M}$, quartz monzonite; Q Sy, quartz syenite; Sye, syenite; Sy Di, syenodiorite; Sy Gb, syenogabbro. Fields of alkalinity modified slightly from those in DeWitt (1989) based on Ed DeWitt (unpub. data, 1994).

(B) Alumina saturation diagram $\left(\mathrm{SiO}_{2}\right.$ versus $\left.\mathrm{A} / \mathrm{CNK}\right)$. $\mathrm{A}$, molar $\mathrm{Al}_{2} \mathrm{O}_{3} ; \mathrm{C}$, molar $\mathrm{CaO} ; \mathrm{N}$, molar $\mathrm{Na}_{2} \mathrm{O} ; \mathrm{K}$, molar $\mathrm{K}_{2} \mathrm{O}$.

(C) Alkali classification diagram $\left(\mathrm{K}_{2} \mathrm{O} /\left(\mathrm{K}_{2} \mathrm{O}+\mathrm{Na}_{2} \mathrm{O}\right)\right.$ versus $\left.\mathrm{SiO}_{2}\right)$. Field boundaries from Ed DeWitt (unpub data, 1994).

(D) Iron enrichment classification diagram $\left(\left(\mathrm{FeO}+0.89 * \mathrm{Fe}_{2} \mathrm{O}_{3}\right) /\left(\mathrm{FeO}+0.89 * \mathrm{Fe}_{2} \mathrm{O}_{3}+\mathrm{MgO}\right)\right.$ versus $\left.\mathrm{SiO}_{2}\right)$. Field boundaries slightly modified from those in DeWitt (1989) based on Ed DeWitt (unpub. data, 1994). 
Intrusive rocks of the Twin Lakes pluton

Rocks described below form the Twin Lakes pluton, a group of intrusive rocks that forms a large pluton and associated dikes in the east-central part of the map area. The Twin Lakes Granodiorite of Brock and Barker forms part of the Twin Lakes pluton; much of it is equivalent to the main body, discussed below

Tti

Intermediate-composition porphyry dikes (Paleocene)-Gray, fine-grained, porphyritic hornblende-biotite tonalite dikes and irregularly shaped plugs. Exposed throughout the Twin Lakes pluton as small dikes and concentrated in the Winfield Peak area as larger masses. Cuts all other parts of the pluton. Consists of 70-85\% groundmass of very fine grained quartz, a mix of feldspars, sericite, and $15-30 \%$ phenocrysts, in decreasing amounts, of turbid to clear oscillatory-zoned and albite-twinned plagioclase, euhedral to strongly embayed quartz, potassium feldspar, biotite slightly altered to chlorite and opaque minerals, skeletal hornblende mostly replaced by opaque minerals, chlorite, minor epidote, sphene, and opaque minerals.

Dikes are predominantly tonalite, a composition not found in many of the other units of the Twin Lakes pluton (fig. 9A). The tonalite is alkali-calcic (fig. 9A), metaluminous to
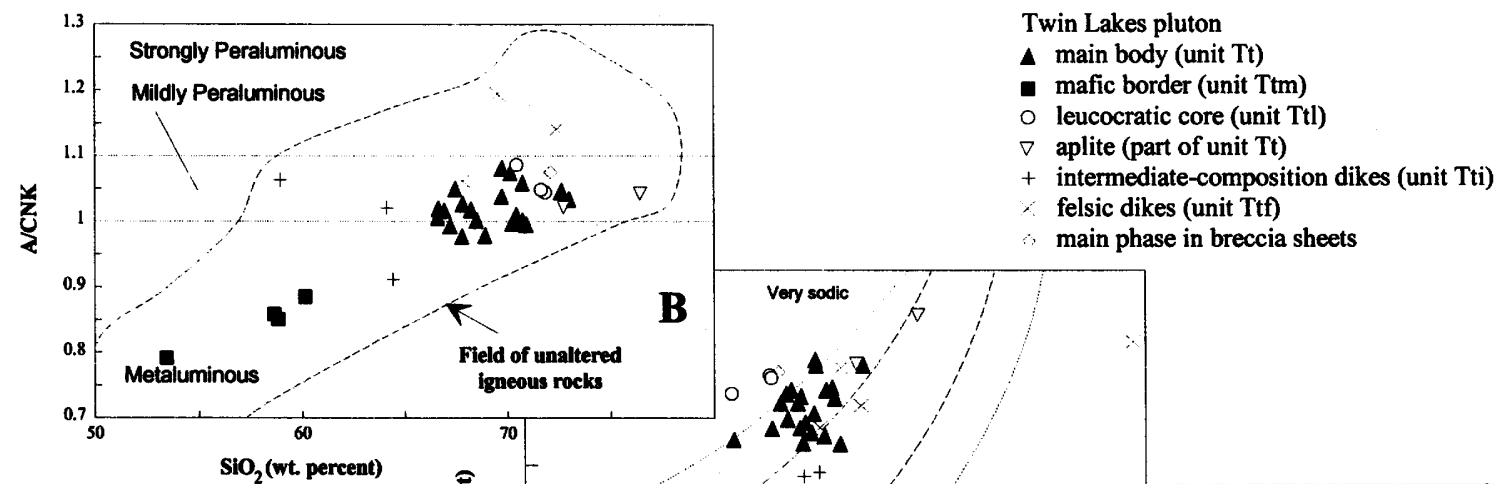

Twin Lakes pluton

main body (unit

+ intermediate-composition dikes (unit Tti)

felsic dikes (unit Ttf)

main phase in breccia sheets

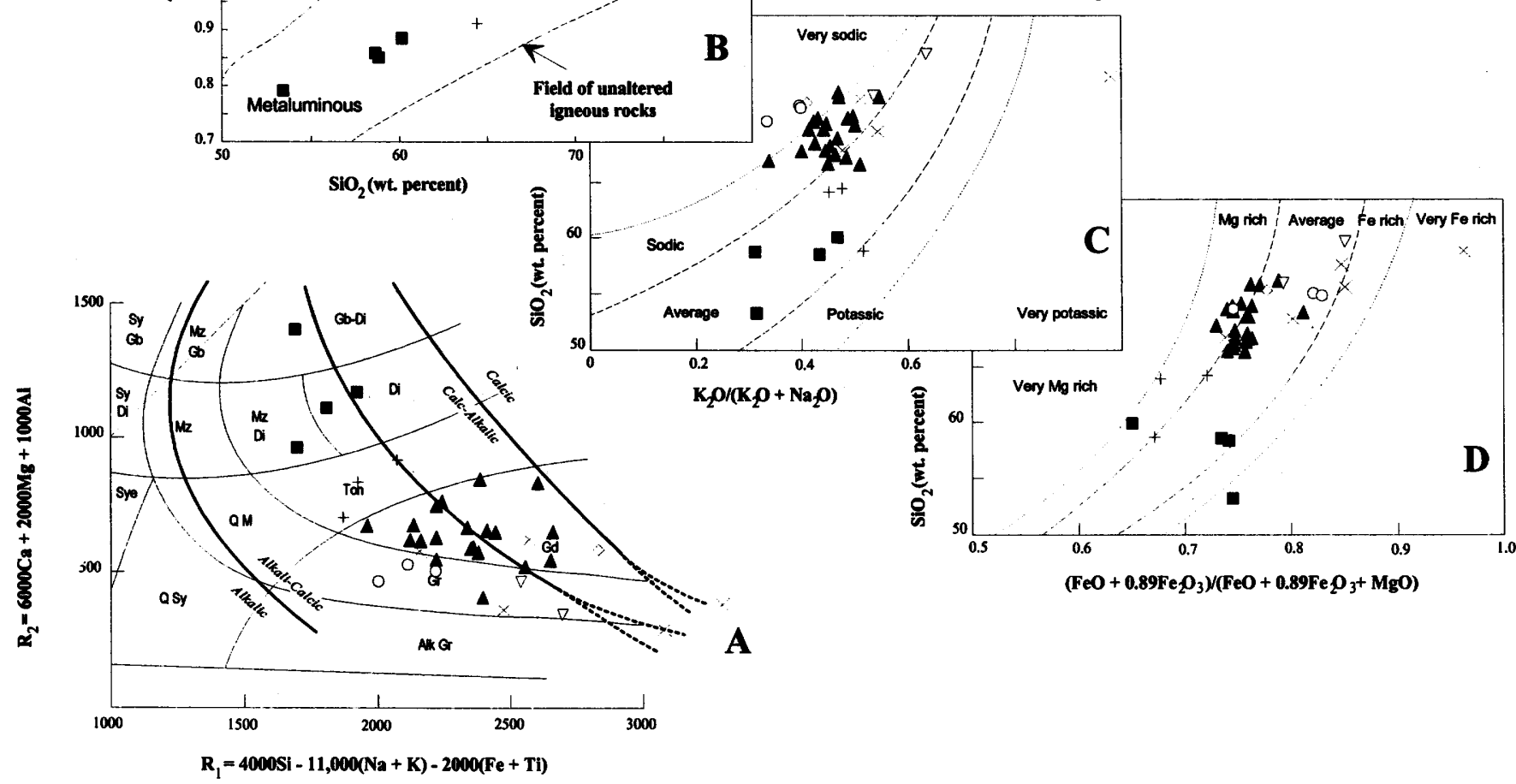

Figure 9. Summary geochemical diagrams for intrusive rocks of the Twin Lakes Pluton. Data from Wilshire (1969), Ed DeWitt (unpub. data, 1994), and Stein and Crock (1990).

(A) $R_{1} R_{2}$ major element classification diagram (De la Roche and others, 1980). Alk Gr, alkali granite; Gr, granite; Gd, granodiorite; Ton, tonalite; $\mathrm{Di}$, diorite; Gb-Di, gabbro-diorite; $\mathrm{Mz} \mathrm{Gb}$, monzogabbro; $\mathrm{Mz} \mathrm{Di}$, monzodiorite; $\mathrm{Q} \mathrm{M}$, quartz monzonite; Q Sy, quartz syenite; Sye, syenite; Sy Di, syenodiorite; Sy Gb, syenogabbro. Fields of alkalinity modified slightly from those in DeWitt (1989) based on Ed DeWitt (unpub. data, 1994).

(B) Alumina saturation diagram $\left(\mathrm{SiO}_{2}\right.$ versus $\left.\mathrm{A} / \mathrm{CNK}\right)$. $\mathrm{A}$, molar $\mathrm{Al}_{2} \mathrm{O}_{3} ; \mathrm{C}$, molar $\mathrm{CaO} ; \mathrm{N}$, molar $\mathrm{Na}_{2} \mathrm{O} ; \mathrm{K}$, molar $\mathrm{K}_{2} \mathrm{O}$.

(C) Alkali classification diagram $\left(\mathrm{K}_{2} \mathrm{O} /\left(\mathrm{K}_{2} \mathrm{O}+\mathrm{Na}_{2} \mathrm{O}\right)\right.$ versus $\left.\mathrm{SiO}_{2}\right)$. Field boundaries from Ed DeWitt (unpub data, 1994).

(D) Iron enrichment classification diagram $\left(\left(\mathrm{FeO}+0.89 * \mathrm{Fe}_{2} \mathrm{O}_{3}\right) /\left(\mathrm{FeO}+0.89 * \mathrm{Fe}_{2} \mathrm{O}_{3}+\mathrm{MgO}\right)\right.$ versus $\left.\mathrm{SiO}_{2}\right)$. Field boundaries slightly modified from those in DeWitt (1989) based on Ed DeWitt (unpub. data, 1994). 
mildly peraluminous (fig. 9B), shows no particular alkali enrichment, and is average to $\mathrm{Mg}$ rich (fig. 9D). The composition of these dikes is believed to be close to the average composition of the magma at depth that was emplaced and fractionally crystallized to form the main body of the Twin Lakes pluton (unit $\mathrm{Tt}$ )

Felsic porphyry dikes (Paleocene)-Lighttan, medium-grained, strongly porphyritic biotite granite and rhyolite dikes. Largest dike exposed on east side of Twin Lakes pluton, from east of Twin Peaks, southward to east of Prospector Gulch in Taylor Park. Dike strikes northerly, dips steeply, and is $17 \mathrm{~km}$ long and 13-26 m wide. Other, smaller dikes in east-central part of map area. Largest dike is quartz monzonite porphyry of Brock and Barker (1972); other bodies include monzonite porphyry and some quartz latite porphyry, both of Brock and Barker (1972). Largest dike has distinctive texture and contains fine-grained groundmass and coarse-grained phenocrysts of potassium feldspar (1-3.5 cm long), plagioclase, and lesser quartz (0.4-0.8 $\mathrm{mm}$ diameter). Other dikes have fine-grained groundmass of quartz, plagioclase, and potassium feldspar, and phenocrysts and clots of oscillatory-zoned and twinned oligoclase, embayed quartz, biotite, and very minor hornblende.

Granite and rhyolite are alkali-calcic to calc-alkalic (fig. 9A), are moderately to strongly peraluminous (fig. 9B), and, considering the limited number of samples, have no apparent alkali enrichment and do not display significant iron enrichment trends (figs. 9C and D). Distinguished from dikes related to Grizzly Peak pluton (units $\mathrm{Tp}$ and $\mathrm{TI}$ ) by strongly zoned plagioclase phenocrysts and high $\mathrm{Sr}$ concentration (700-1,000 ppm). Dikes for which chemical analyses indicate certainty in classification are indicated on map with small box on dike symbol. Dikes that lack chemical samples but that are inferred to belong to this unit on the basis of petrography are indicated by no box on the dike symbol.

Tt Main body (Paleocene)-Light-gray and tan, medium- to coarse-grained, equigranular to strongly porphyritic biotite granodiorite and associated compositionally layered rocks and aplite bodies. Major rock unit in east-central part of area, from south flank of Mount Elbert to Taylor Park. Layered granodiorite most common along east-west-trending contacts with Early Proterozoic rocks on either side of Lake Creek. Cuts and is gradational into mafic border (unit Ttm), and it is gradational into leucocratic core (unit $\mathrm{Tt} \mathrm{l}$ ). Aplites, including aplite body at Monitor Rock (Wilshire, 1969), cut the main body and are gradational to it. Includes normal facies of Brock and Barker (1972). Fine-grained, equigranular granodiorite restricted to outcrops at East Red, just inside the ring fault of the Grizzly Peak caldera; may be a higher-level textural equivalent of the medium- to coarse-grained granodiorite outside the caldera. Fine-grained granodiorite has been down-dropped in the caldera. Coarse-grained granodiorite contains variable concentrations of conspicuous Carlsbadtwinned perthite and orthoclase phenocrysts as large as $5 \mathrm{~cm}$ by $15 \mathrm{~cm}$ and slightly embayed quartz phenocrysts as large as 1.2 cm (Chapman, 1935; Wilshire, 1969; Brock and Barker, 1972). Consists, in decreasing order, of oscillatory-zoned and albitetwinned oligoclase, perthite and orthoclase, quartz, biotite, opaque minerals, hornblende, sphene, and minor amounts of apatite, zircon, and trace allanite.

Main body is a granodiorite that is alkali-calcic (fig. 9A). Points that plot in calc-alkalic field are lacking the normal concentration of coarse-grained potassium feldspar phenocrysts. The granodiorite is metaluminous to mildly peraluminous (fig. 9B), is average to sodic (fig. 9C), and average to $\mathrm{Mg}$ rich (fig. 9D). Distinctive chemical features of the granodiorite are its high $\mathrm{Sr}$ concentration (650-1050 ppm) and low $\mathrm{P}_{2} \mathrm{O}_{5}$ ( 0.18 weight percent average). Aplite bodies are granite that is alkali-calcic (fig. 9A), mildly peraluminous (fig. 9B), and that lacks significant alkali enrichment or iron enrichment trends (figs. 9C and D).

Fission-track apatite dates of 16-30 Ma, fission-track sphene and zircon dates of 39-44 $\mathrm{Ma}, \mathrm{K}-\mathrm{Ar}$ biotite date of $42 \mathrm{Ma}$, and $\mathrm{Rb}-\mathrm{Sr}$ biotite dates of 49-56 Ma (summarized by Wallace, 1993, 1995) from main body of granodiorite and from aplite are uplift and cooling dates of the Paleocene pluton

Ttl Leucocratic core (Paleocene)-Light-gray to creamy-white, medium-grained, equigranular biotite granite. Distinctive leucocratic nature and lack of potassium-feldspar phenocrysts separate core from other units of the Twin 
Lakes pluton. Exposed on Jenkins Mountain and in upper reaches of North Fork of Clear Creek. Grades into main body (unit Tt). Lacks conspicuous perthite and orthoclase phenocrysts. Cut by minor aplite and intermediate porphyry dikes.

Leucocratic core is an alkali-calcic granite (fig. 9A) that is mildly peraluminous (fig. 9B), very sodic (fig. 9C), and shows no significant iron enrichment (fig. 9D). Characterized by very low Th concentrations $(<1.2-3.0$ ppm) and low $\mathrm{P}_{2} \mathrm{O}_{5}$ ( $<0.05$ weight percent). Outcrop extent corresponds to Th low on radiometric maps of the central Sawatch Range (D.L. Campbell and J. Duval, written commun., 1988)

Ttm Mafic border (Paleocene)-Dark-greenishgray, medium-grained, equigranular to slightly porphyritic hornblende gabbrodiorite, monzodiorite, and diorite. Exposed discontinuously on the southwestern margin of the pluton near Grizzly Peak, near the southwestern corner of the pluton near Huron Peak, and on the northwestern margin of the pluton, within the Grizzly Peak caldera, near the head of South Fork of Lake Creek. Both gradational into and intruded by main body. Includes border facies of Brock and Barker (1972). Consists, in decreasing amounts, of oscillatory-zoned and albite-twinned andesine to oligoclase, hornblende, potassium feldspar having minor perthitic texture, quartz, opaque minerals, biotite, sphene, and minor amounts of apatite and zircon.

Mafic border has an average composition of diorite (fig. 9A), is alkali-calcic (fig. 9A), metaluminous (fig. 9B), lacks any alkali enrichment (fig. 9C), and varies from $\mathrm{Mg}$ rich to Fe rich (fig. 9D). Characterized by high concentrations of $\mathrm{Sr}$ (800-1,200 ppm). Distinguished from Cretaceous diorite (unit $\mathrm{Kd}$ ) by alkali-calcic nature.

Paleocene age assignment based on ${ }^{40} \mathrm{Ar}-{ }^{39} \mathrm{Ar}$ hornblende plateau date of $63.8 \pm$ 1.4 Ma from sample collected north of Lake Pass (table 2, fig. 10; Shannon and others, 1987)

Quartz porphyry, granite, and aplite (Cretaceous)-Light-tan to cream or pink, finegrained, equigranular, leucocratic quartz porphyry, muscovite granite, aplite, and hydrothermally altered aplite. Exposed in far northwestern part of area, near Richmond Hill, where sills of all rock types cut Paleozoic rocks as young as the Pennsylvanian

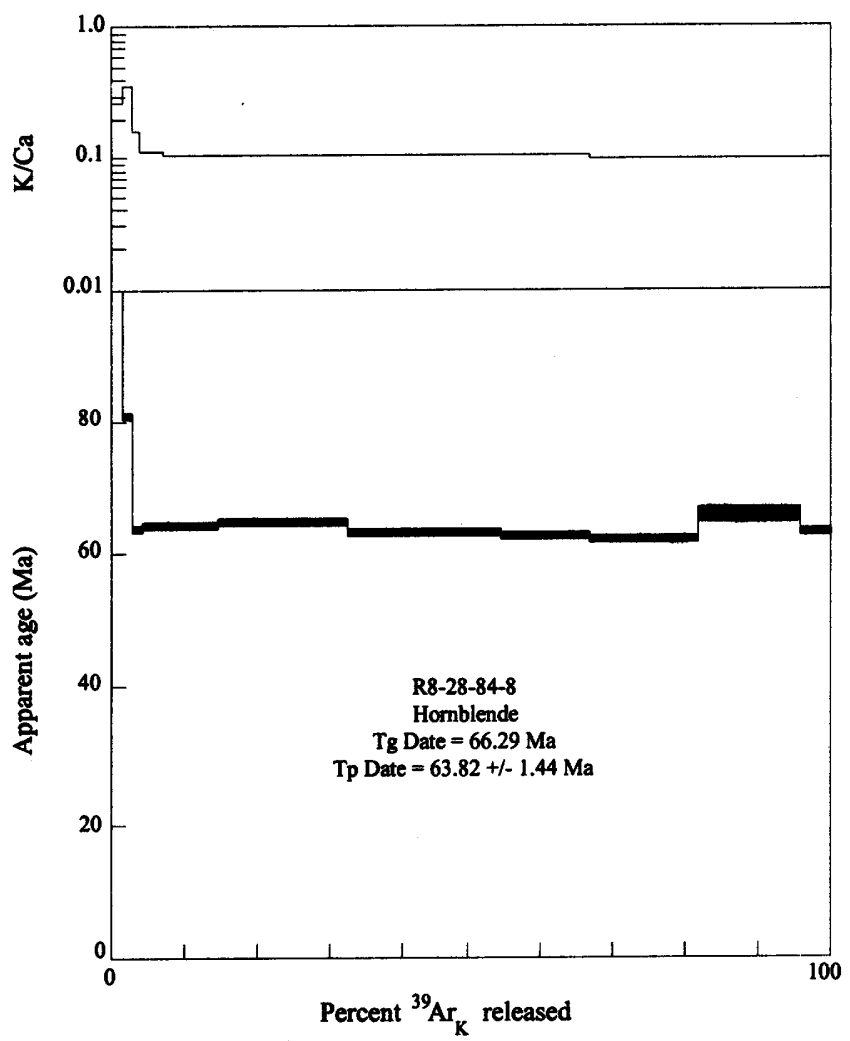

Figure 10. ${ }^{40} \mathrm{Ar}-{ }^{39} \mathrm{Ar}$ release spectra for hornblende from sample R8-28-84-8 of mafic border of Twin Lakes pluton. Width of bars on spectra is 2-sigma uncertainty.

Belden Formation (Bryant, 1970). Possibly equivalent to the Late Cretaceous Pando Porphyry north of Leadville (Pearson and others, 1962). Exposed as dikes paralleling foliation in Early Proterozoic metasedimentary gneiss west and north of Grizzly Peak caldera, from New York Peak to Mount Champion (Ludington and Yeoman, 1980), and as similar dikes in area centered on Granite, in the Arkansas River graben. Quartz porphyry contains conspicuous phenocrysts of quartz and muscovite and is composed, in decreasing amounts, of quartz, plagioclase, potassic feldspar, biotite, muscovite, opaque minerals, and minor amounts of epidote and apatite. Aplite and altered aplite contain fewer phenocrysts and less biotite.

Near Aspen, unaltered sills and plugs range from granodiorite to granite (fig. 4A), are strongly peraluminous (fig. 4B), sodic (fig. $4 C$ ), and Fe rich to very Fe rich (fig. 4D). Hydrothermally altered rocks are calc-alkalic (fig. 4A), as a result of feldspar destruction, and strongly peraluminous (fig. 4B). Disseminated pyrite in the altered rocks explains the 
very Fe-rich nature of the quartz porphyry and aplite. In the area from Mount Champion to northwest of Independence Pass, unaltered dikes are granite that is alkali-calcic (fig. 7A), strongly peraluminous (fig. 7B), sodic (fig. 7C), and average to $\mathrm{Mg}$ rich (fig. 7D). Altered dikes in this area are much more strongly peraluminous and, although not shown on figure $7 \mathrm{~B}$, they would plot above the field of unaltered rocks (fig. 7B). Altered dikes are very potassic (fig. $7 \mathrm{C}$ ) and have an average iron enrichment (fig. 7D). Minor element geochemistry (Mosier and others, 1980) indicates that the Cretaceous dikes in this area can be distinguished from dikes related to the Grizzly Peak caldera by their high $\mathrm{Sr}$ concentrations and low $\mathrm{Zr}$ and $\mathrm{Nb}$ concentrations at comparable $\mathrm{SiO}_{2}$ concentrations. Dikes for which chemical analyses indicate certainty in classification are indicated on map with small box on dike symbol. Dikes that lack chemical samples but that are inferred to belong to this unit on the basis of petrography are indicated by no box on the dike symbol.

Cretaceous age based on $\mathrm{K}$-Ar whole-rock date of $65.4 \pm 2.4 \mathrm{Ma}$ (Van Loenen and others, 1989) for dike north of Independence Pass and 65.3 $\pm 2.4 \mathrm{Ma}$ (Hedlund, 1985) for dike northeast of Granite, both of which are interpreted as minimum ages for emplacement of the dikes

Dioritic intrusive rocks (Cretaceous)-Darkgreenish-gray, medium-grained, equigranular hornblende-biotite diorite to granodiorite stocks and sills. Exposed south of Aspen in the Richmond Hill area as sills and discordant bodies cutting Paleozoic strata as young as the Pennsylvanian Belden Formation. Also exposed as stocks east of the Twin Lakes pluton in three areas: north of Missouri Mountain; at and west of the Lienhart Mine; and along Morrison Creek west of the Arkansas River.

Near Richmond Hill the diorite is the hornblende quartz diorite of Bryant (1970, 1979), which is in contact with quartz porphyry (unit $\mathrm{Kr}$ ). Contact relations of the two igneous rocks are poorly exposed (Bryant, 1979). Diorite near Richmond Hill is an altered, porphyritic rock containing phenocrysts of hornblende and plagioclase. Altered diorite consists, in decreasing order, of plagioclase, epidote, chlorite, opaque minerals, quartz, carbonate minerals, muscovite, and minor sphene and apatite. Altered diorite is alkali- calcic (fig. 4A), metaluminous (fig. 4B), potassic (fig. 4C), and very Fe-rich (fig. 4D).

North of Missouri Mountain, diorite forms a 1.5 by $3 \mathrm{~km}$, east-west-elongate stock cut by the eastern border of the Twin Lakes pluton. The diorite, between Lake Fork and Pecks Peak, is the granodiorite unit of Brock and Barker (1972) and is medium grained, equigranular, and consists, in decreasing amounts, of andesine, quartz, biotite, hornblende, potassium feldspar, opaque minerals, and minor amounts of sphene and apatite. The diorite is calc-alkalic (fig. 11A), metaluminous (fig. 11B), and has no apparent alkali or iron enrichment (fig. 11C and D). The diorite has high concentrations of $\mathrm{Sr}$ (750-800 ppm), which is typical for rocks of this unit.

At and west of the Lienhart Mine, an irregular-shaped, east-west-elongate body intrudes the Kroenke Granodiorite. This body is compositionally zoned, from dark-greenish-black, coarse-grained, equigranular gabbro to tan, medium-grained, equigranular granophyre. Mafic rock types are most numerous at the southwestern margin of the body, on the south-facing slopes above Frenchman Creek. Felsic rocks crudely overlie the mafic rocks toward the top of the ridge, but the body lacks well developed igneous layering. Gabbro consists of predominantly actinolitic hornblende and plagioclase, and lesser biotite, apatite, potassium feldspar, quartz, and magnetite. Tonalite has plagioclase, quartz, hornblende, biotite, potassium feldspar, and lesser opaque minerals, apatite, sphene, and allanite. Granophyre contains more quartz and less hornblende than tonalite. The body ranges from olivine gabbro to granodiorite (fig. 11A; olivine gabbro plots above the diagram), and averages tonalite. Rocks in the range diorite to granodiorite are calc-alkalic (fig. 11A), metaluminous to mildly peraluminous (fig. 11B), and have no alkali or iron enrichment (figs. 11C and D). Distinctive features of the intrusive body at the Lienhart Mine include its zoned nature and the low concentration of $\mathrm{Rb}$ (65 ppm average).

The body along Morrison Creek, west of the Arkansas River, is poorly exposed because of forest and glacial cover. The intrusive rock is finer grained and more porphyritic than the other diorite bodies and contains more quartz-pyrite-chalcopyrite veinlets and altered zones. No chemistry is available for this body. 


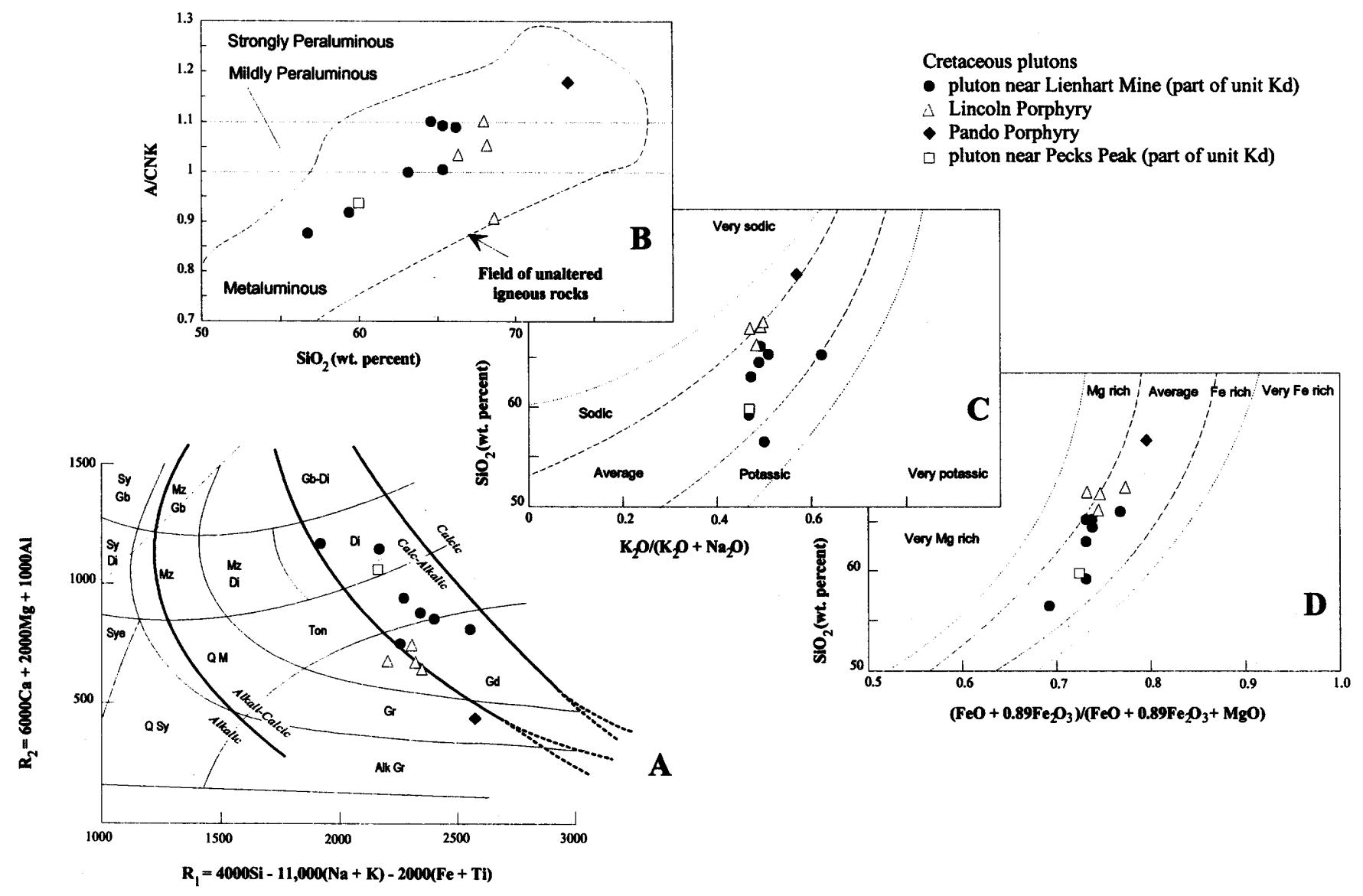

Figure 11. Summary geochemical diagrams for Cretaceous plutons east of the Twin Lakes pluton. Data from Ed DeWitt (unpub. data, 1994). Lincoln Porphyry included for purposes of camparison to the Twin Lakes pluton.

(A) $R_{1} R_{2}$ major element classification diagram (De la Roche and others, 1980). Alk Gr, alkali granite; Gr, granite; Gd, granodiorite; Ton, tonalite; $\mathrm{Di}$, diorite; $\mathrm{Gb}$ - $\mathrm{Di}$, gabbro-diorite; $\mathrm{Mz} \mathrm{Gb}$, monzogabbro; $\mathrm{Mz} \mathrm{Di}$, monzodiorite; $\mathrm{Q} \mathrm{M}$, quartz monzonite; Q Sy, quartz syenite; Sye, syenite; Sy Di, syenodiorite; Sy Gb, syenogabbro. Fields of alkalinity modified slightly from those in DeWitt (1989) based on Ed DeWitt (unpub. data, 1994).

(B) Alumina saturation diagram $\left(\mathrm{SiO}_{2}\right.$ versus $\left.\mathrm{A} / \mathrm{CNK}\right)$. $\mathrm{A}$, molar $\mathrm{Al}_{2} \mathrm{O}_{3} ; \mathrm{C}$, molar $\mathrm{CaO} ; \mathrm{N}$, molar $\mathrm{Na}_{2} \mathrm{O} ; \mathrm{K}$, molar $\mathrm{K}_{2} 0$.

(C) Alkali classification diagram $\left(\mathrm{K}_{2} \mathrm{O} /\left(\mathrm{K}_{2} \mathrm{O}+\mathrm{Na}_{2} \mathrm{O}\right)\right.$ versus $\left.\mathrm{SiO}_{2}\right)$. Field boundaries from Ed DeWitt (unpub data, 1994).

(D) Iron enrichment classification diagram $\left(\left(\mathrm{FeO}+0.89 * \mathrm{Fe}_{2} \mathrm{O}_{3}\right) /\left(\mathrm{FeO}+0.89 * \mathrm{Fe}_{2} \mathrm{O}_{3}+\mathrm{MgO}\right)\right.$ versus $\left.\mathrm{SiO}_{2}\right)$. Field boundaries slightly modified from those in DeWitt (1989) based on Ed DeWitt (unpub. data, 1994).

Cretaceous age assignment for all bodies of diorite is based on observation that the 63.8-Ma Twin Lakes pluton cuts the diorite north of Missouri Mountain. Also, Knopf (1926) suggested that dioritic rocks in the Aspen area were older than 67-74-Ma quartz porphyry sills (summarized in Bryant, 1979). Similar dioritic rocks in the northern Sawatch Range have K-Ar dates as old as 70 Ma (Wallace and Blaskowski, 1989; Wallace, 1993; 1995). We infer, therefore, that the diorite bodies in the map area are older than $64 \mathrm{Ma}$, but no older than Cretaceous

\section{KJme Mancos Shale through Entrada Sandstone,} undivided (Upper Cretaceous through
Middle Jurassic)—Exposed at Hunters Hill in far southwestern part of area (Zoerner, 1974). Includes:

Mancos Shale (Upper Cretaceous)-Darkgray, silty shale and thin beds of siltstone and fine-grained sandstone. About $55 \mathrm{~m}$ thick

Dakota Sandstone (Lower Cretaceous) White to light-gray and yellowish-gray quartzite, sandstone, conglomeratic sandstone, and dark-gray carbonaceous shale. About $92 \mathrm{~m}$ thick

Morrison Formation (Upper Jurassic)Greenish-red and greenish-gray shale, siltstone, mudstone, and sandstone. At least 115 m thick 
Entrada Sandstone (Middle Jurassic)White to yellowish-gray and pale-red, crossbedded sandstone and a few lenses of conglomerate near the base. About $55 \mathrm{~m}$ thick

PPmb Maroon Formation through Belden Formation, undivided (Lower Permian through Pennsylvanian)-Exposed in far western part of map area, from Richmond Hill to south of Italian Mountain (Bryant, 1970). Includes:

Maroon Formation (Lower Permian to Middle Pennsylvanian)-Grayish-red to reddish-brown calcareous sandstone, mudstone, conglomerate, and limestone. Minor anhydrite in lower part. Thickest unmetamorphosed sections exposed on Timbered Hill and southwest of Hunters Hill, in far southwestern part of map area. Exposed as large screens within White Rock pluton, where rocks are contact metamorphosed to green and gray calc-silicate hornfels and white quartzite. Approximate thickness in map area $920 \mathrm{~m}$

Gothic Formation (Middle Pennsylvanian) Gray, tan, and brown calcareous sandstone, siltstone, shale, silty limestone, and limestone. Sparse anhydrite and gypsum beds. Locally metamorphosed to hornfels, quartzite, and marble adjacent to Tertiary intrusive rocks. Apparent thickness 136-920 m. True thickness difficult to estimate because of thrust faults, especially the Elk Range thrust, that are localized within the formation

Belden Formation (Middle and Lower Pennsylvanian)-Black to dark-gray limestone, dolomite, shale, and carbonaceous shale containing a few sandstone beds and thin lenses of chert pebble conglomerate near base. Pyritic in part. Crops out poorly. Best exposed southwest of Taylor Pass. Contact metamorphosed to marble and hornfels near Tertiary intrusive rocks. Some of the marble superficially resembles marble of the Leadville Limestone. Apparent thickness $227-575 \mathrm{~m}$. True thickness difficult to estimate because of thrust faults

MEls Leadville Limestone through Sawatch Quartzite (Lower Mississippian through Upper Cambrian)—All formations in unit exposed extensively in far western part of area, from Richmond Hill to Italian Mountain (Bryant, 1970; Cunningham, 1976). Sawatch Quartzite exposed southwest and southeast of Cottonwood Pass (Brock and Barker, 1972). Sawatch Quartzite and Manitou Dolomite exposed beneath Grizzly Peak caldera fill along Bowman Creek. Includes:
Leadville Limestone (Lower Mississippian)-Consists of two members. Thickness 45-67 m

Castle Butte Cliff Member-Gray, massive limestone

Red Cliff Member-Gray to dark-gray, thin to thick-bedded dolomite and a few beds of limestone in lower part. Contact metamorphosed to marble near Tertiary intrusive bodies. Thickness 45-67 m

Chaffee Group (Lower Mississippian? and Upper Devonian)-Consists of three formations. Thickness 30-60 m

Gilman Sandstone (Lower Mississippian or Upper Devonian)-Dolomitic sandstone, sandy dolomite, and sedimentary breccia

Dyer Dolomite (Upper Devonian) - Lightto dark-gray, thin- to thick-bedded dolomite and a few beds of gray limestone

Parting Formation (Upper Devonian)White to tan quartzite, gray to green shale, and dolomitic shale. Thickness $30-60 \mathrm{~m}$

Fremont Limestone (Upper Ordovician)Gray, massive dolomite. Thickness $10 \mathrm{~m}$. Included with Manitou Dolomite in southwestern part of map area

Harding Sandstone (Middle Ordovician)Dolomitic sandstone containing fossil fish plates. Thickness 1-3 m. Included with Manitou Dolomite in southwestern part of map area

Manitou Dolomite (Lower Ordovician)Gray dolomite containing white chert stringers and nodules in upper part. Thickness 45-100 m

Peerless Formation (Upper Cambrian)Brown-weathering, locally glauconitic dolomitic sandstone, sandy dolomite, and gray-green and grayish-red shale. A few beds of white quartzite locally near base. Thickness $30-45 \mathrm{~m}$

Sawatch Quartzite (Upper Cambrian)White quartzite containing some beds of brown dolomitic sandstone and at the base a quartz-pebble conglomerate less than $1 \mathrm{~m}$ thick. Thickness near Cottonwood Pass $35 \mathrm{~m}$. Thickness near Italian Mountain $67 \mathrm{~m}$

Ys St. Kevin Granite (Middle Proterozoic)Light-tan to pinkish-tan, fine- to mediumgrained, equigranular biotite-muscovite granite (Tweto and Pearson, 1964). Undeformed, but flow-foliated and compositionally layered in places. Consists, in decreasing percentages, of microcline, quartz, plagioclase, biotite, and muscovite, and trace amounts of 
apatite, zircon, fluorite, and sillimanite. Most St. Kevin in map area corresponds to fine-grained facies of Tweto (1974). Pegmatite sills and dikes as thick as $10 \mathrm{~m}$ common, but not shown on map. Many small bodies that intrude unit Xms not shown. Some small bodies of granite and pegmatite west and south of New York Peak, in the western part of the area, could be 1700-Ma rocks rather than St. Kevin. Intrudes schist and metasedimentary gneiss (unit $\mathrm{Xms}$ ), gneissic granodiorite (unit $\mathrm{Xgd}$ ), leucocratic and normal granite of Henry Mountain (units Xhl, Xh), Kroenke Granodiorite (unit $X k$ ), and cuts Grottos Granodiorite (unit $\mathrm{Yg}$ ) at the head of Lost Man Creek. Distinguished from Grottos
Granodiorite by equigranular texture, greater abundance of feldspar, lack of mafic border, much lower magnetic susceptibility, subdued aeromagnetic response (Tweto and Case, 1972; Godson and others, 1985), and somewhat higher scintillometer readings, indicating higher concentration of radioactive elements.

The granite is alkali-calcic (fig. 12A), mildly to strongly peraluminous (fig. 12B), average to potassic (fig. 12C), and has no apparent iron enrichment (fig. 12D). Elevated concentrations of $\mathrm{Zr}(300-600 \mathrm{ppm})$ and Th (40-60 ppm) are common. Muscovite-rich granite and pegmatite are identical in chemistry to the main body, but slightly more

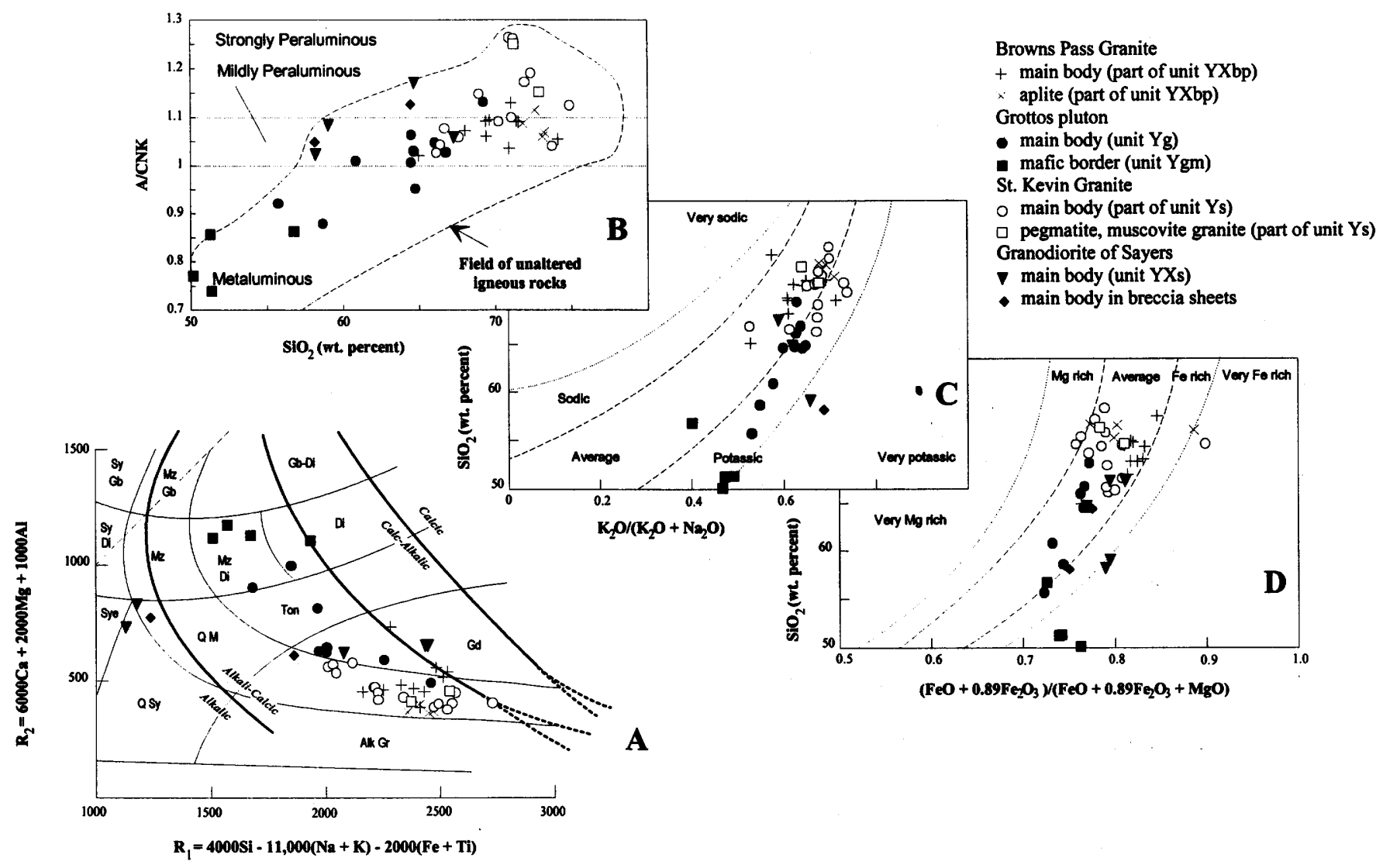

Figure 12. Summary geochemical diagrams for 1.4-Ga plutons and plutons assumed to be $1.4 \mathrm{Ga}$ in the central Sawatch Range area. Data from Ed DeWitt (unpub. data, 1994), Barker and Brock (1965), and Tweto and Pearson (1964).

(A) $R_{1} R_{2}$ major element classification diagram (De la Roche and others, 1980). Alk Gr, alkali granite; Gr, granite; Gd, granodiorite; Ton, tonalite; $\mathrm{Di}$, diorite; Gb-Di, gabbro-diorite; $\mathrm{Mz} \mathrm{Gb}$, monzogabbro; $\mathrm{Mz} \mathrm{Di}$, monzodiorite; $\mathrm{Q} \mathrm{M}$, quartz monzonite; Q Sy, quartz syenite; Sye, syenite; Sy Di, syenodiorite; Sy Gb, syenogabbro. Fields of alkalinity modified slightly from those in DeWitt (1989) based on Ed DeWitt (unpub. data, 1994).

(B) Alumina saturation diagram $\left(\mathrm{SiO}_{2}\right.$ versus $\left.\mathrm{A} / \mathrm{CNK}\right)$. A, molar $\mathrm{Al}_{2} \mathrm{O}_{3} ; \mathrm{C}$, molar $\mathrm{CaO} ; \mathrm{N}$, molar $\mathrm{Na}_{2} \mathrm{O} ; \mathrm{K}$, molar $\mathrm{K}_{2} \mathrm{O}$.

(C) Alkali classification diagram $\left(\mathrm{K}_{2} \mathrm{O} /\left(\mathrm{K}_{2} \mathrm{O}+\mathrm{Na}_{2} \mathrm{O}\right)\right.$ versus $\left.\mathrm{SiO}_{2}\right)$. Field boundaries from Ed DeWitt (unpub data, 1994).

(D) Iron enrichment classification diagram $\left(\left(\mathrm{FeO}+0.89 * \mathrm{Fe}_{2} \mathrm{O}_{3}\right) /\left(\mathrm{FeO}+0.89 * \mathrm{Fe}_{2} \mathrm{O}_{3}+\mathrm{MgO}\right)\right.$ versus $\left.\mathrm{SiO}_{2}\right)$. Field boundaries slightly modified from those in DeWitt (1989) based on Ed DeWitt (unpub. data, 1994). 
strongly peraluminous (fig. 12B). Elevated concentrations of $\mathrm{Rb}$ (340-380 ppm) are characteristic.

In the northern Sawatch Range, the St. Kevin has a seven-point whole-rock $\mathrm{Rb}-\mathrm{Sr}$ isochron date of $1420 \pm 100 \mathrm{Ma}$ (recalculated by DeWitt using program of Ludwig, 1990, and data of Pearson and others, 1966). Large uncertainty in the $\mathrm{Rb}-\mathrm{Sr}$ isochron date is probably due to inhomogeneity of initial Sr-isotope ratio, which averages $0.7034 \pm$ 0.007 . U-Pb zircon discordia upper intercept date of $1395 \pm 65 \mathrm{Ma}$ (recalculated by DeWitt using program of Ludwig, 1990, and data of Doe and Pearson, 1969) is for two least discordant zircon fractions and their acid leaches or same two zircon fractions and a forced lower discordia intercept of $70 \mathrm{Ma}$.

Two zircon fractions for an outcrop of St. Kevin Granite that cuts metasedimentary gneiss (unit Xms) east of Italian Mountain, in the southwestern part of area, have a U-Pb discordia upper intercept date of $1446 \mathrm{Ma}$ (fig. 13, table 3). No uncertainty is calculated for the regression, as we have only two dated zircon fractions. The date of $1446 \mathrm{Ma}$ is slightly older than the dates discussed above, and may indicate that the St. Kevin Granite is slightly older than previously thought.

\section{Intrusive rocks of the Grottos pluton}

Ygl Leucocratic bodies (Middle Proterozoic)Light-tan to creamy-tan, fine- to mediumgrained, equigranular biotite-muscovite granite. In small outcrops north and south of The Grottos and southwest of Taggerts Lake. Other small bodies probably present in Grot-

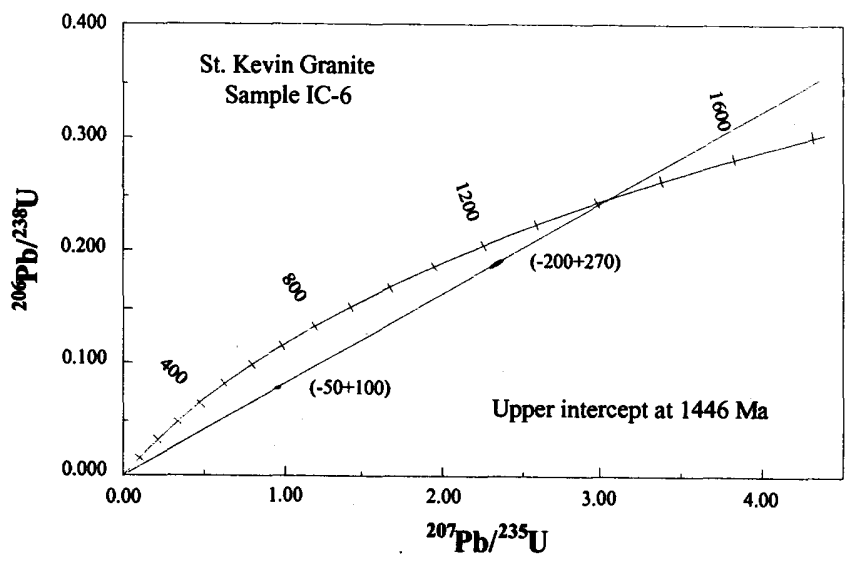

Figure 13. Concordia diagram for zircon from sample IC- 6 of the St. Kevin Granite. Size of symbol represents 2-sigma analytical uncertainty. tos Granodiorite on Smuggler Mountain, but not mapped in this reconnaissance. Much granite is highly fractured and susceptible to landslide failure, as exhibited by large rock avalanche that extends from Mount Shimer to below Weller Lake along the Roaring Fork River. Consists, in decreasing amounts, of microcline, plagioclase, quartz, biotite, muscovite, and trace amounts of apatite and magnetite. Grades into and intrudes main body (unit $\mathrm{Yg}$ ) and intrudes metasedimentary gneiss (unit Xms)

Yg Main body (Middle Proterozoic)-Mediumtan to grayish-tan, medium- to coarsegrained, equigranular biotite tonalite to granite in large, irregularly zoned pluton in northwestern part of map area. Contains conspicuous magnetite and sphene. Tectonically undeformed, but slightly flow-foliated in places. Named herein for exposures along the Roaring Fork River, at and below The Grottos, on the steep south-facing slopes of Smuggler Mountain, and on the steep, northeast-facing slopes of New York Peak. Pluton extends north beyond map area into the Hunter and Fryingpan Creek drainages, as indicated by surface geology and aeromagnetic signature (Campbell, 1981), and west, beneath Phanerozoic rocks, toward Castle Creek. Prominent aeromagnetic high coincides with central part of pluton (Campbell and Wallace, 1986). Granodiorite consists, in decreasing amounts, of plagioclase, quartz, biotite, microcline, magnetite, sphene, and muscovite, and trace amounts of apatite, allanite, zircon, and epidote. Granite consists, in decreasing amounts, of quartz, microcline, plagioclase, biotite, muscovite, and magnetite, and trace amounts of sphene, apatite, and zircon. Intrudes schist and metasedimentary gneiss (unit Xms) and St. Kevin Granite (unit Ys) in upper reaches of Lost Man Creek. Grades laterally into and also cuts discordantly its mafic border (unit Ygm). Grades laterally into and also is cut discordantly by its leucocratic part (unit $\mathrm{Ygl}$ ).

Composition of the body ranges from monzodiorite to granodiorite and averages granodiorite (fig. 12A). All the compositions are alkali-calcic (fig. 12A), are metaluminous to mildly peraluminous (fig. 12B), are average to potassic (fig. 12C), and mostly have no apparent iron enrichment (fig. 12D). Elevated concentrations of $\mathrm{TiO}_{2}$ (1-2 weight percent), $\mathrm{P}_{2} \mathrm{O}_{5}$ (0.5-0.9 weight percent), $\mathrm{Sr}$ 
(300-500 ppm), and $\mathrm{Zr}(400-600 \mathrm{ppm})$ common in granodiorite and tonalite contrast to most 1400-Ma plutons in the southwestern United States. Exceptions are 1400-Ma mafic plutons such as the Mount Evans and Oak Creek plutons in the Front Range of Colorado (Aleinikoff and others, 1993; Noblett and others, 1987), which resemble the Grottos Granodiorite.

Age assignment based on undeformed nature, chemical similarity to known 1400-Ma plutons in Colorado, and fact that body is cut by St. Kevin Granite

Ygm Mafic border (Middle Proterozoic)-Darkgreenish-gray to dark-gray and tan, mediumgrained biotite monzodiorite and tonalite. Most abundant on southwestern margin of pluton near McArthur Mountain. Smaller outcrops at Upper Grottos Campground near mouth of Ptarmigan Creek and in northeast-trending sill-like body between Midway Pass and Scotts Lake. Very rich in biotite, sphene, and magnetite. Monzodiorite and tonalite consist, in decreasing amounts, of plagioclase, biotite, quartz, microcline, magnetite, sphene, and epidote, and trace amounts of apatite, allanite, and zircon. Notable for lack of hornblende. Intrudes schist and metasedimentary gneiss (unit Xms).

Monzodiorite and tonalite are alkali-calcic (fig. 12A), metaluminous (fig. 12B), potassic (fig. 12C), and are Fe rich to very Fe rich (fig. 12D). Anomalously high concentration of $\mathrm{Sr}$ (500-800 ppm), $\mathrm{TiO}_{2}$ (2-3 weight percent), and $\mathrm{P}_{2} \mathrm{O}_{5}$ (1.5-2.0 weight percent) characterize the mafic border

Yt Granite of Taylor River (Middle Proterozoic)-Light-tan, fine- to medium-grained, equigranular to slightly porphyritic muscovite-biotite granite. Informally named by DeWitt and others (1985) for exposures in the Fossil Ridge area, southwest of the map area. Crops out southwest of Dinner Station Campground in Taylor Park and along Illinois Creek. Intrudes metasedimentary gneiss (unit $X m s$ ), quartzite (unit $X q$ ), and granite of Henry Mountain (unit Xh). Undeformed and unaltered except where cut by extensive northwest-striking, high-angle shear zone in far southern part of area. Extends southwest into Fossil Ridge area where it forms a pluton 18 by $18 \mathrm{~km}$ in extent. Was included in parts of units $\mathrm{Yg}$ and $\mathrm{YXg}$ of Tweto (1979).

Chemically the granite is alkali-calcic, strongly peraluminous, and is average to iron rich. Characteristically, the granite has $\mathrm{Sr}$ and $\mathrm{Zr}$ concentrations less than $100 \mathrm{ppm}$ and $\mathrm{U}$ concentrations of 4-14 ppm.

Middle Proterozoic age is based on $\mathrm{Rb}-\mathrm{Sr}$ geochronology of Wetherill and Bickford (1965) and U-Th- $\mathrm{Pb}$ geochronology by $\mathrm{Ed}$ DeWitt and R.E. Zartman (unpub. data, 1990). Sample \#CO-64 of Wetherill and Bickford (1965), from along the Taylor River southwest of the map area, has a whole-rock potassium feldspar-plagioclase-muscovite isochron of $1380 \pm 19 \mathrm{Ma}$ (recalculated by DeWitt using program of Ludwig, 1990). One zircon fraction from a sample along the Taylor River southwest of the map area has a ${ }^{207} \mathrm{~Pb} / 206 \mathrm{~Pb}$ date of $1406 \mathrm{Ma}$ (Ed DeWitt and R.E. Zartman, unpub. data, 1990)

YXs Granodiorite of Sayers (Middle or Early Proterozoic)-Medium- to dark-gray, medium- to coarse-grained, equigranular to strongly porphyritic biotite quartz syenite to granodiorite. Mild to strong flow foliation strikes northeast and dips variably. Subsolidus fabric present in southern outcrops of granodiorite. Composed, in decreasing amounts, of perthite, oligoclase to albite, quartz, biotite, chloritized biotite, opaque minerals, and minor, but conspicuous, apatite and zircon. Exposed northwest of Winfield Peak and south of Sayers mineral monument. Intrudes Kroenke Granodiorite (unit $\mathbf{X k}$ ) and metasedimentary gneiss (unit Xms). Includes complex of layered gneisses of Brock and Barker (1972).

Igneous rock has wide range in composition, from quartz syenite to granodiorite. Quartz syenite is alkalic (fig.12A), mildly peraluminous (fig. 12B), very potassic (fig. $12 \mathrm{C}$ ), and very iron rich (fig. 12D). Granodiorite is calc-alkalic (fig. 12A), mildly peraluminous (fig. 12B), and has no preferred alkali or iron enrichment (figs. 12C and D). Characteristically, the granodiorite of Sayers has high $\mathrm{K}_{2} \mathrm{O}$ (5-6.3\%), high $\mathrm{Zr}$ and $\mathrm{Sr}(500$ to $800 \mathrm{ppm}$ each), and high $\mathrm{Ba}(2800-4500$ ppm).

Age assignment based on flow foliated to slightly tectonized texture, unusual alkalic composition, which is indicative of $1.4-\mathrm{Ga}$ plutons in the southwestern United States (E. DeWitt, unpub. data, 1993), and fact that the body intrudes the Kroenke Granodiorite

YXbp Browns Pass Granite (Middle or Early Proterozoic)-Light-tan, medium-grained, equigranular, undeformed, leucocratic biotitemuscovite granite and aplite. Originally 
named the Browns Pass Quartz Monzonite (Barker and Brock, 1965), the body is redescribed herein as granite because of new chemical analyses, map relations, and additional petrographic studies. Exposed in southern part of area, from southwestern Taylor Park to Avalanche Gulch on east slope of Mount Yale. Small masses of Browns Pass Granite along Langhoff Gulch at eastern edge of map and east of Twin Lakes Reservoir at northeastern edge of map may be part of separate 1.4-Ga intrusive body along Big Union Creek to the east of the map. Intrudes Kroenke Granodiorite (unit $\mathrm{Xk}$ ), granite of Mount Yale (unit Xy), Denny Creek Granodiorite (unit $\mathrm{Xd}$ ), metasedimentary gneiss (unit Xms), and quartzite (unit Xq). Consists of medium-grained, equigranular to porphyritic biotite granite, fine-grained, equigranular biotite-muscovite granite, and fine-grained leucocratic aplitic masses and dikes. Granite consists, in decreasing order of microcline and perthite, quartz, characteristic turbid oligoclase, biotite and chloritized biotite, opaque minerals, muscovite, and minor apatite, allanite, and zircon. Aplite contains same minerals, but lesser amounts of opaque minerals, biotite, allanite, and zircon.

The granite is alkali-calcic (fig. 12A), mildly to strongly peraluminous (fig. 12B), and has no preferred alkali enrichment and no iron enrichment (figs. 12C and D). Compared to most $1.4-\mathrm{Ga}$ plutons in the southwestern United States and Colorado (Ed DeWitt, unpub. data, 1993), the Browns Pass has low $\mathrm{Rb}$ concentrations (average of $200 \mathrm{ppm}$ ) for an evolved granite. Aplitic bodies and dikes of the granite have a chemistry similar to the main granite (fig. 12).

Middle or Early Proterozoic age assignment based on fact that aplitic masses and dikes of Browns Pass cut the Kroenke Granodiorite and that the chemistry of the granite is similar to dated 1.4-Ga plutons in central Colorado. Barker and Brock (1965) suggested that the Browns Pass was older than the Kroenke because brecciated rocks on the western slope of Mount Yale that they inferred were older than the Browns Pass were cut by the pluton. These brecciated rocks were not identified as Kroenke in their mapping.

Xk Kroenke Granodiorite (Early Proterozoic)Light-gray, medium-grained, equigranular, undeformed, but compositionally layered, leucocratic biotite granodiorite, granite, and biotite aplite. Minor subsolidus fabric locally overprints igneous compositional layers. Major rock unit in eastern third of map area; smaller outlier west of Mount Elbert. Equivalent to granodiorite of Fairview Peak in Fossil Ridge area to the southwest (DeWitt and others, 1985). Not recognized in Sawatch Range north of map area (Tweto, 1974; Van Loenen, 1985; Wallace and others, 1986). Intrudes metasedimentary gneiss (unit Xms), Denny Creek Granodiorite (unit Xd), gneissic granodiorite (unit Xgd), and granite of Mount Yale (unit $X y$ ). Thin slivers of metasedimentary gneiss (unit $\mathrm{Xms}$ ) present along much of the contact between Kroenke and Denny Creek, as if Kroenke preferentially intruded the metasedimentary gneiss unit. Overall, leucocratic rock has compositional layers defined by biotite-rich and biotite-poor material. Complexly layered Kroenke Granodiorite resembles schlieren or migmatite in outcrop. Consists, in decreasing order, of plagioclase, quartz, potassic feldspar, biotite and biotite altered to chlorite, opaque minerals, hornblende, and minor amounts of sphene, apatite, allanite rimmed by epidote, and zircon. Aplitic varieties have less biotite, sphene, and opaque minerals than main granodiorite.

Body ranges from granodiorite to granite (fig. 14A), is alkali-calcic to calc-alkalic (fig. 14A), mildly to strongly peraluminous (fig. 14B), sodic to very sodic (fig. 14C), and average to $\mathrm{Mg}$ rich (fig. 14D). Distinctive features of the Kroenke include its $\mathrm{Na}$-rich and $\mathrm{Mg}$-rich nature, and low concentrations of $\mathrm{Zr}$ and $\mathrm{P}_{2} \mathrm{O}_{5}$ (175 ppm and 0.14 weight percent, respectively). Barker and others (1976) classify the Kroenke as a trondhjemite because of its sodic chemistry.

Early Proterozoic age assignment based on published $\mathrm{Rb}-\mathrm{Sr}$ and unpublished $\mathrm{U}-\mathrm{Pb}$ sphene analyses. Barker and others (1974) obtained a $1670 \pm 100$ Ma date (Model 1 date recalculated by DeWitt using the program of Ludwig, 1990) from 6 whole-rock samples of Kroenke in the Sawatch Range (also cited by Reed and others, 1987). A U-Pb sphene date of $1645 \pm 5 \mathrm{Ma}$ was obtained from a sample of Kroenke just south of Rockdale, along Clear Creek (J. Aleinikoff and J. Reed, unpub. data, 1991) 


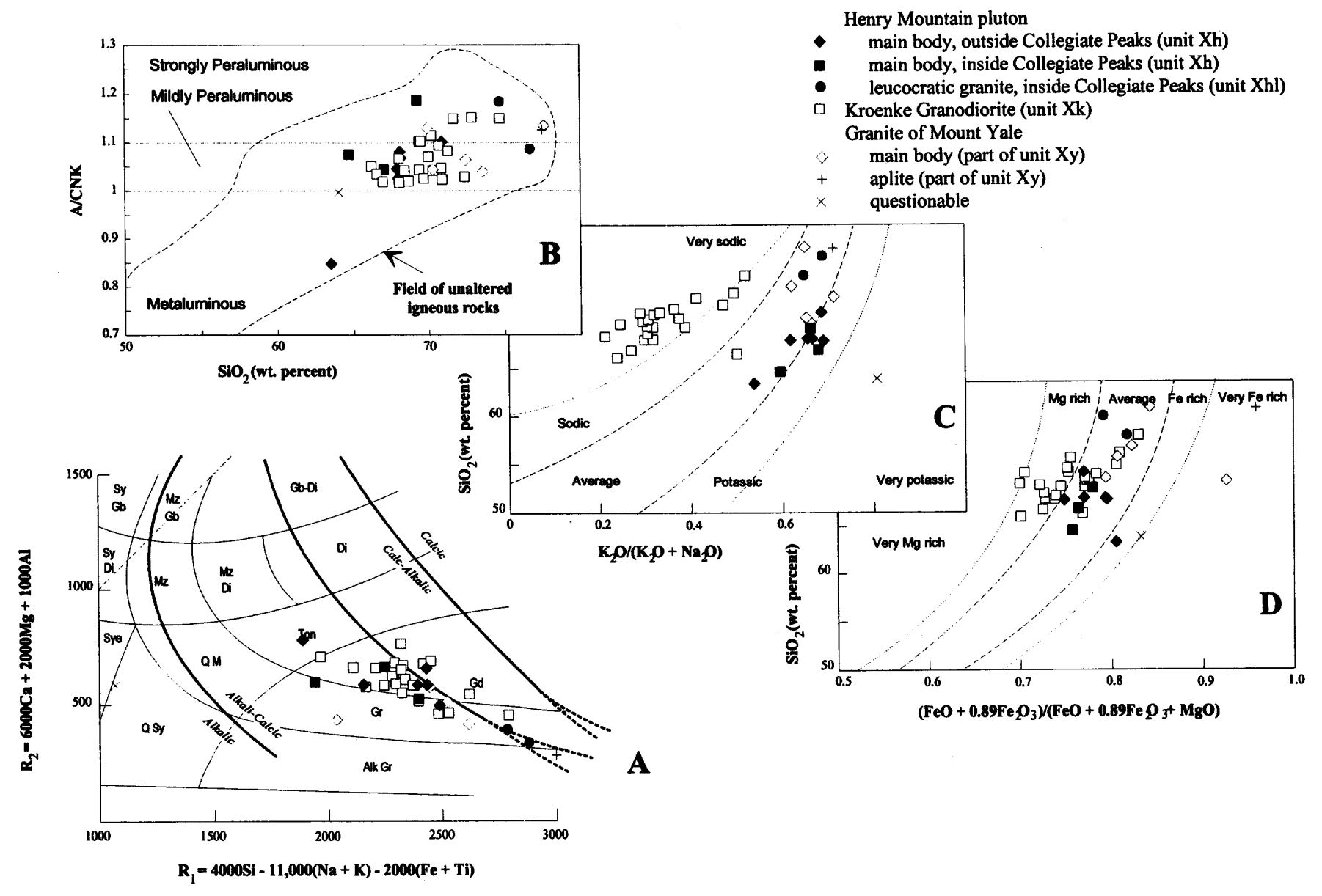

Figure 14. Summary geochemical diagrams for some $1.65-\mathrm{Ga}$ and older plutons in the central Sawatch Range area. Plot includes the Kroenke Granodiorite, granite of Henry Mountain, and granite of Mount Yale. Data from Ed DeWitt (unpub. data, 1994), Barker and Brock (1965), and Barker and others (1976).

(A) $R_{1} R_{2}$ major element classification diagram (De la Roche and others, 1980). Alk Gr, alkali granite; Gr, granite; Gd, granodiorite; Ton, tonalite; $\mathrm{Di}$, diorite; Gb-Di, gabbro-diorite; $\mathrm{Mz} \mathrm{Gb}$, monzogabbro; $\mathrm{Mz} \mathrm{Di}$, monzodiorite; $\mathrm{Q} \mathrm{M}$, quartz monzonite; Q Sy, quartz syenite; Sye, syenite; Sy Di, syenodiorite; Sy Gb, syenogabbro. Fields of alkalinity modified slightly from those in DeWitt (1989) based on Ed DeWitt (unpub. data, 1994).

(B) Alumina saturation diagram $\left(\mathrm{SiO}_{2}\right.$ versus $\left.\mathrm{A} / \mathrm{CNK}\right)$. $\mathrm{A}$, molar $\mathrm{Al}_{2} \mathrm{O}_{3} ; \mathrm{C}$, molar $\mathrm{CaO} ; \mathrm{N}$, molar $\mathrm{Na}_{2} \mathrm{O} ; \mathrm{K}$, molar $\mathrm{K}_{2} \mathrm{O}$.

(C) Alkali classification diagram $\left(\mathrm{K}_{2} \mathrm{O} /\left(\mathrm{K}_{2} \mathrm{O}+\mathrm{Na}_{2} \mathrm{O}\right)\right.$ versus $\left.\mathrm{SiO}_{2}\right)$. Field boundaries from Ed DeWitt (unpub data, 1994).

(D) Iron enrichment classification diagram $\left(\left(\mathrm{FeO}+0.89 * \mathrm{Fe}_{2} \mathrm{O}_{3}\right) /\left(\mathrm{FeO}+0.89 * \mathrm{Fe}_{2} \mathrm{O}_{3}+\mathrm{MgO}\right)\right.$ versus $\left.\mathrm{SiO}_{2}\right)$. Field boundaries slightly modified from those in DeWitt (1989) based on Ed DeWitt (unpub. data, 1994).

\section{Xhl}

\section{Intrusive rocks of the Henry Mountain pluton}

Leucocratic granite bodies (Early Proterozoic)-Light-tan to creamy-white, mediumgrained, equigranular to slightly porphyritic, leucocratic granite to alaskite. Exposed to the east and west of Taylor Pass, at the northwest head of Taylor Park. Includes the granite (unit $p € g$ ) of Bryant (1970). Granite to alaskite cuts and is gradational into granite of Henry Mountain (unit Xh). Leucocratic body contains distinctive quartz phenocrysts but lacks the microcline phenocrysts and abundant biotite of the granite of
Henry Mountain. Consists, in decreasing amounts, of microcline, quartz, sodic oligoclase, muscovite, biotite, minor opaque minerals, and trace amounts of apatite and zircon.

The leucocratic granite to alaskite is on the border of alkali-calcic and calc-alkalic (fig. $14 \mathrm{~A}$ ), is mildly to strongly peraluminous (fig. 14B), and has no apparent alkali or iron enrichment (figs. 14C and D).

The leucocratic granite is assumed to be a late-crystallizing equivalent of the granite of Henry Mountain 

zoic)-Pinkish-tan and black, coarsegrained, undeformed, strongly porphyritic biotite-muscovite granite. Informally named by DeWitt and others (1985) for exposures in Fossil Ridge area to southwest of map area. Includes the porphyritic quartz monzonite (unit p Epq) of Bryant (1970) in northern Taylor Park. Exposed continuously along the southwestern side of Taylor Park, from north of Taylor Pass to south of Dinner Station Campground. Intrudes metasedimentary gneiss (unit Xms) and gneissic granodiorite (unit Xgd). In Hunter-Fryingpan Wilderness to north of map area, Hell Gate Porphyry (Tweto and Pearson, 1964) is the northern equivalent of the granite of Henry Mountain. Granite contains conspicuous phenocrysts of perthitic microcline and quartz. Consists, in decreasing amounts, of microcline, quartz, albite to sodic oligoclase, biotite, muscovite, magnetite, and ilmenite, and minor amounts of apatite, zircon, allanite, and epidote.

The body ranges from granodiorite to granite, is alkali-calcic (fig. 14A), mildly to strongly peraluminous (fig. 14B), is slightly potassic (fig. 14C), and has no iron enrichment (fig. 14D). The granite is characterized by moderate to high Y (40-60 ppm) and low $\mathrm{Ba}$ (many analyses $<550 \mathrm{ppm}$ ) for a rock that contains so much potassium feldspar.

Early Proterozoic age assignment based on published and unpublished $\mathrm{U}-\mathrm{Th}-\mathrm{Pb}$ geochronology. Bickford and Boardman (1984) and Bickford and others (1989) report a U-Pb upper intercept date of $1701 \pm 10$ Ma for zircon from the granite at Indian Head, south of the Fossil Ridge area. This date is in agreement with a ${ }^{207} \mathrm{~Pb} /{ }^{206} \mathrm{~Pb}$ date of $1693 \mathrm{Ma}$ from one fraction of zircon collected from a sample of the granite along the Taylor River, southwest of the map area (Ed DeWitt and R.E. Zartman, unpub. data, 1990)

\section{Intrusive rocks of the Denny Creek Pluton}

Leucocratic bodies (Early Proterozoic)Tawny-brown to brownish-gray, mediumgrained, equigranular, compositionally layered and tectonically foliated biotite granodiorite. Exposed in central part of area, from southwestern margin of Grizzly Peak caldera along Tellurium Creek, to south of the Three Apostles, north of Texas Creek. Also exposed along northwestern margin of Grizzly Peak caldera. Grades into main Denny Creek Granodiorite (unit $\mathbf{X d}$ ). Typically is compositionally layered rock, having layers of biotite-rich and biotite-poor granodiorite to granite. In many western exposures, layers are buckled and folded, giving the rock the appearance of "tiger stripes." Intrudes metasedimentary gneiss (unit Xms) and gneissic granodiorite (unit $\mathrm{Xgd}$ ). Consists, in decreasing amounts, of oligoclase, quartz, perthite, biotite, opaque minerals, and minor amounts of sphene, zircon, apatite, and allanite.

Chemically, leucocratic or "tiger stripe" part ranges from granodiorite to granite, is alkali-calcic to calc-alkalic (fig. 15A), strongly peraluminous (fig. 15B), and has no strong alkali or iron enrichment (figs. 15C, D). Similar to the main Denny Creek Granodiorite (unit Xd), the leucocratic body has elevated concentrations of $\mathrm{Zr}$ and $\mathrm{Y}$

Main body of Denny Creek Granodionite (Early Proterozoic)-Dark-grayish brown to greenish-black, coarse-grained, equigranular to strongly porphyritic, undeformed to strongly tectonically foliated biotite-rich granodiorite. Exposed from Independence Pass to beyond southern border of map area. Originally named the Denny Creek Granodiorite Gneiss (Barker and Brock, 1965). Granodiorite is undeformed east of a line from west of Mount Elbert, through Vicksburg, west of the summits of Mount Oxford and Mount Harvard, and on to the mouth of Cottonwood Creek. Denny Creek Granodiorite south of Texas Creek to Cottonwood Pass is mostly undeformed, but contains some zones of highly strained granodiorite. Much of the Denny Creek north of Texas Creek and south of Hamilton is strongly tectonized. Exposed both at type area along Denny Creek, southwest of Mount Yale, and along the cliffs on either side of Clear Creek, below Vicksburg. Denny Creek intrudes metasedimentary gneiss (unit Xms), quartzite (unit $X q$ ), and gneissic granodiorite (unit $\mathrm{Xgd}$ ). Granodiorite consists, in decreasing amounts, of oligoclase, quartz, perthite, biotite, ilmenite and magnetite, and minor amounts of sphene, apatite, allanite, zircon, and chlorite. Distinguishing features include the abundance of biotite (as much as 20 volume percent), variable but high percentage of sphene, and low concentration of hornblende.

The body ranges from monzodiorite to granodiorite, but averages granodiorite (fig. 15A). Most compositions are calc-alkalic, but 

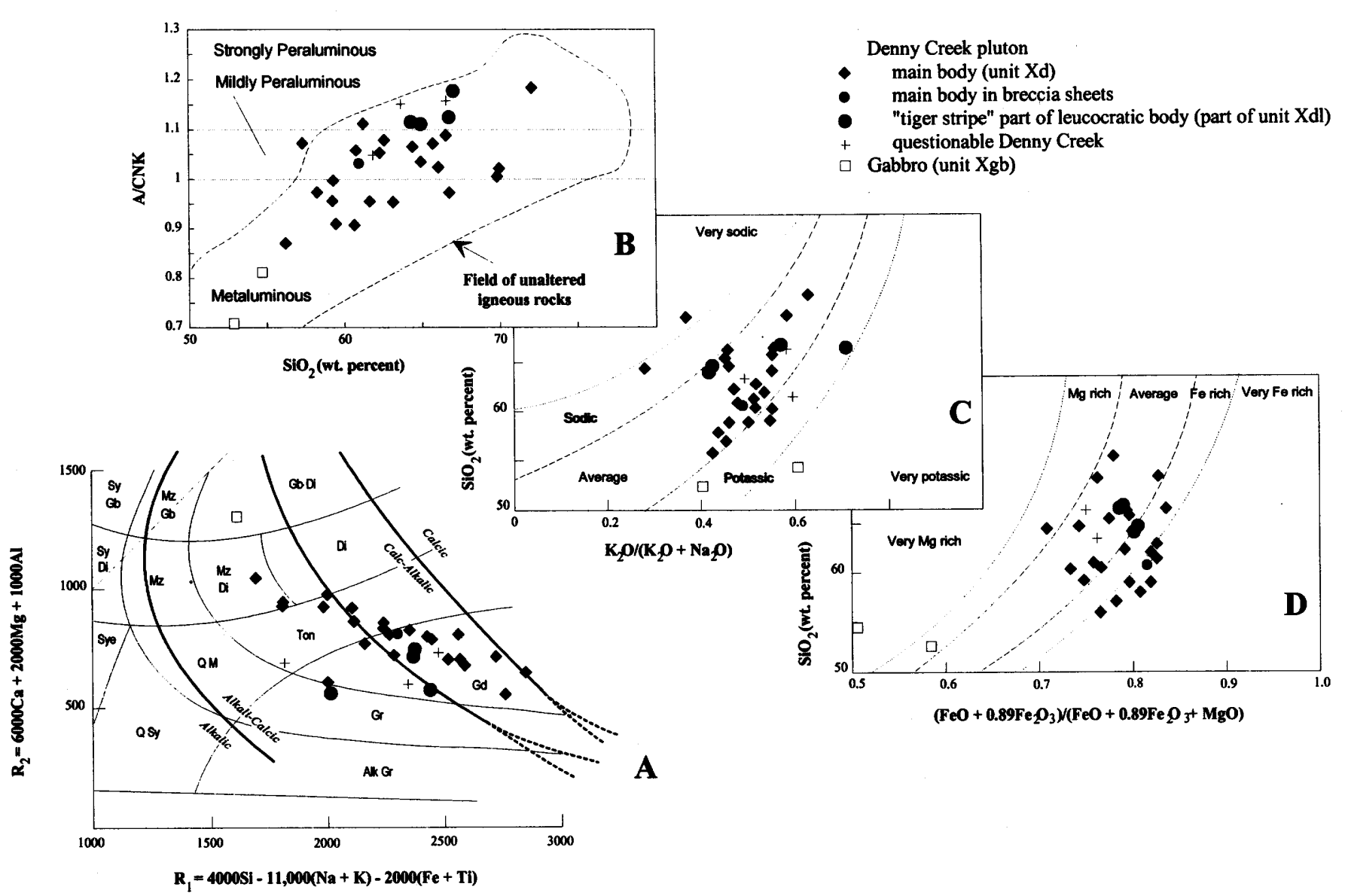

Figure 15. Summary geochemical diagrams for some 1.70-Ga and older plutons in the central Sawatch Range area. Plot includes the Denny Creek Granodiorite and unnamed gabbro. Data from Ed DeWitt (unpub. data, 1994), and Barker and Brock (1965).

(A) $R_{1} R_{2}$ major element classification diagram (De la Roche and others, 1980). Alk Gr, alkali granite; Gr, granite; Gd, granodiorite; Ton, tonalite; $\mathrm{Di}$, diorite; Gb-Di, gabbro-diorite; $\mathrm{Mz} \mathrm{Gb}$, monzogabbro; $\mathrm{Mz} \mathrm{Di}$, monzodiorite; $\mathrm{Q} \mathrm{M}$, quartz monzonite; Q Sy, quartz syenite; Sye, syenite; Sy Di, syenodiorite; Sy Gb, syenogabbro. Fields of alkalinity modified slightly from those in DeWitt (1989) based on Ed DeWitt (unpub. data, 1994).

(B) Alumina saturation diagram $\left(\mathrm{SiO}_{2}\right.$ versus $\left.\mathrm{A} / \mathrm{CNK}\right)$. $\mathrm{A}$, molar $\mathrm{Al}_{2} \mathrm{O}_{3} ; \mathrm{C}$, molar $\mathrm{CaO} ; \mathrm{N}$, molar $\mathrm{Na}_{2} \mathrm{O} ; \mathrm{K}$, molar $\mathrm{K}_{2} 0$.

(C) Alkali classification diagram $\left(\mathrm{K}_{2} \mathrm{O} /\left(\mathrm{K}_{2} \mathrm{O}+\mathrm{Na}_{2} \mathrm{O}\right)\right.$ versus $\left.\mathrm{SiO}_{2}\right)$. Field boundaries from Ed DeWitt (unpub data, 1994).

(D) Iron enrichment classification diagram $\left(\left(\mathrm{FeO}+0.89 * \mathrm{Fe}_{2} \mathrm{O}_{3}\right) /\left(\mathrm{FeO}+0.89 * \mathrm{Fe}_{2} \mathrm{O}_{3}+\mathrm{MgO}\right)\right.$ versus $\left.\mathrm{SiO}_{2}\right)$. Field boundaries slightly modified from those in DeWitt (1989) based on Ed DeWitt (unpub. data, 1994).

some granodiorite is alkali-calcic, probably the result of early crystallization of abundant biotite (fig. 15A). The most mafic bodies are metaluminous, but much of the granodiorite ranges from moderately to strongly peraluminous (fig. 15B); as a whole the Denny Creek is mildly peraluminous. No strong alkali enrichment patterns are evident (fig. 15C). Most of the compositions are average to very Fe rich (fig. 15D). Characteristic features of the Denny Creek are its high $\mathrm{Zr}$ concentration (averaging $400 \mathrm{ppm}$ ), high $\mathrm{Y}$ concentration (50-70 ppm), low slope on the $R_{1} R_{2}$ diagram, and mildly to strongly peraluminous character for a rock so low in $\mathrm{SiO}_{2}$. Also, the granodiorite does not become more $\mathrm{Fe}$ rich as differentiation index increases.

Age designation based on observation that Denny Creek is cut by the Kroenke Granodiorite and that the Denny Creek has been regionally deformed, possibly twice, in its western exposures. No geochronologic data are available for the Denny Creek Granodiorite

Xkd Kroenke Granodiorite and Denny Creek Granodiorite, undivided (Early Proterozoic)Mixture of Denny Creek Granodiorite, much of it strongly deformed, and Kroenke Granodiorite. Includes minor bodies of amphibolite 
(unit Xam) and metasedimentary gneiss (unit

Xms). Exposed at and near the Three Apostles

Xdi Diorite (Early Proterozoic)-Medium-graygreen, medium-grained, equigranular to slightly porphyritic, well flow-foliated plagioclase-hornblende diorite. Prominent dike exposed south of Alan Lake where it cuts metasedimentary gneiss (unit Xms) and is cut by Kroenke Granodiorite (unit Xk) and by simple pegmatite bodies believed to be related to granodiorite of Sayers (unit YXs). Body of metasedimentary gneiss, Kroenke Granodiorite, and simple pegmatite bodies at Alan Lake too small to be shown on map. Tectonic fabric locally superimposed on flow foliation near contact with metasedimentary gneiss. Contact between diorite and granodiorite of Sayers (unit YXs) obscured by intermediate-composition porphyry dike of the Twin Lakes pluton that is not shown on the map because of its small size. Consists, in decreasing order, of poorly twinned plagioclase, phenocrysts of hornblende, perthite, quartz, biotite, epidote, opaque minerals, and minor amounts of allanite, apatite, sphene, and zircon. No chemical or geochronologic data are available to further refine the age of the diorite

Xgd Gneissic granodiorite (Early Proterozoic)Homogeneous to heterogeneous gneissic granodiorite to granite bodies, many having layers of alternating biotite-rich and biotite-poor material. Superimposed subsolidus fabric common, but not widespread. Exposed along Bowman Creek at northwest end of Taylor Park, at the head of Sayers Gulch, at Grizzly Peak south of Jenkins Mountain, on the south slope of Mount Elbert, and along the heavily forested east-facing slopes of Mount Harvard, Mount Columbia, and Mount Yale. Bodies at the first three localities are homogeneous, layered biotite granodiorite. Those at the other localities are more heterogeneous, range from biotite granodiorite to leucocratic granite, and contain inclusions of metasedimentary gneiss. Outcrops east of Mount Yale contain great variety of plutonic rock types and migmatite. Intrudes metasedimentary gneiss (unit $\mathrm{Xms}$ ). Consists, in decreasing order, of perthite, oligoclase, quartz, biotite, muscovite, opaque minerals, and minor amounts of zircon, allanite, apatite, and sphene.

There are no chemical data for bodies within the map area. However, similar gneissic granodiorite bodies in the Fossil
Ridge area to the southwest range in composition from tonalite to granite, are calc-alkalic to alkali-calcic, and moderately to strongly peraluminous.

Early Proterozoic age assignment based on fact that bodies are cut by the granite of Henry Mountain, the Denny Creek Granodiorite, and the Kroenke Granodiorite

Xy Granite of Mount Yale (Early Proterozoic)Light-cream to white, fine- to coarse- grained, equigranular to porphyritic, massive to foliated, leucocratic granite to alaskite. Exposed on Mount Yale and possibly within gneissic granodiorite (unit $X g d$ ) to the east of Mount Yale. Intrudes metasedimentary gneiss (unit $\mathrm{Xms}$ ) and gabbro (unit Xgb). Granite of Mount Yale and gneissic granodiorite (unit Xgd) on east slopes of Mount Yale are interlayered; age relations of the two are equivocal. Includes complex of brecciated gneisses of Brock and Barker (1972). Typically has two parts, a coarse-grained, equigranular to porphyritic, perthite-rich biotite granite, and a fine-grained, equigranular, leucocratic to alaskitic aplite that may or may not be associated with pegmatite bodies. Biotite granite consists, in decreasing order, of perthite and microcline, quartz, biotite, plagioclase, magnetite, muscovite, apatite, and minor amounts of allanite. Aplite consists of perthite and microcline, quartz, plagioclase, magnetite, biotite, muscovite, and minor amounts of zircon.

The main body ranges from granodiorite to granite, is alkali-calcic (fig. 14A), mildly to strongly peraluminous (fig. 14B), and predominantly shows no strong alkali or iron enrichment (figs. 14C and D). The aplite is an alkali granite (fig. 14A), strongly peraluminous (fig. 14B), and very Fe rich (fig. 14D). Characteristic features of the granite are its $\mathrm{Rb}$-rich and Zr-rich nature (150-175 ppm and 180-600 ppm, respectively), and low Sr concentration (40-160 ppm).

Early Proterozoic age assignment based on observation that granite of Mount Yale is intruded by the Denny Creek Granodiorite and Kroenke Granodiorite

Xgb Gabbro and metagabbro (Early Proterozoic)-Dark-greenish black, medium- to coarse-grained, equigranular to slightly foliated hornblende gabbro. Mappable bodies most common in southeastern part of map area, from north of Cottonwood Pass to east of Mount Yale. Smaller, unmapped bodies are 
along Frenchman and Three Elk Creeks, east of Mount Columbia. Intrudes metasedimentary gneiss (unit $\mathrm{Xms}$ ), but is most numerous as large inclusions in Denny Creek Granodiorite (unit Xd) and granite of Mount Yale (unit $X y$ ). Consists, in decreasing order, of coarse-grained aggregates of plagioclase and hornblende in a finer grained matrix of quartz, hornblende, biotite, and minor amounts of allanite, sphene, and opaque minerals.

Chemical data for this unit are minimal. The two samples indicate that these mafic rocks range from gabbro to gabbro-diorite (fig. 15A; gabbro plots above the diagram), are alkali-calcic (fig. 15A), metaluminous (fig. 15B), potassic to very potassic (fig. 15C), and $\mathrm{Mg}$ rich to very $\mathrm{Mg}$ rich (fig. $15 \mathrm{D}$ ). At least two suites probably are present, one with moderate $\mathrm{Sr}$ concentrations (400-600 ppm) and one with very high $\mathrm{Sr}$ concentrations (1,500-1,800 ppm)

Xam Amphibolite (Early Proterozoic)-Darkgreenish-black, medium-grained, equigranular, well-foliated hornblende-plagioclase gneiss and amphibole schist. Exposed in small bodies west of Harrison Flat, east of Mount Yale, and south of Cottonwood Pass. Many amphibolite masses are too small to be shown at the scale of the map. Relict pillow textures preserved in outcrops south of Cottonwood Pass and farther south in Tincup area (Brock and Barker, 1972) suggest that amphibolite bodies are metamorphosed basalt flows. Includes hornblende-plagioclase gneiss and amphibolite of Brock and Barker (1972). Consists, in decreasing order, of andesine, hornblende, biotite, quartz, opaque minerals, and minor amounts of sphene and apatite

Metasedimentary gneiss (Early Proterozoic)Heterogeneous assemblage of quartzofeldspathic gneiss, micaceous gneiss, amphibolite, and minor granitic intrusive rocks. Unit widespread in map area. Largest mass is northwest of Grizzly Peak caldera, but extends from Taylor Pass to Deer Mountain, and on to Mount Elbert. Smaller masses in the southern part of the Grizzly Peak caldera near Lake Pass, south of Twin Lakes Reservoir, east of Mount Columbia, east and west of Mount Yale, south of Cottonwood Pass, and in northwest-trending belts at the Three Apostles and on the west side of Taylor Park.

Quartzofeldspathic gneiss containing biotite, muscovite, garnet, and sillimanite is common north and west of the Grizzly Peak caldera. Interlayered amphibolite, actinolite gneiss, and intermediate-composition metavolcanic rocks are most common south of Mount Elbert, in the northwest-trending belt at the Three Apostles, and in the north-trending belt east of Mount Yale. Typical rock types in northwest-trending belt at the Three Apostles include: amphibolite gneiss; biotite-amphibole gneiss; migmatite; quartzfeldspar gneiss; quartz-feldspar-biotite gneiss and schist; fine-grained, equigranular granite gneiss; actinolite-rich amphibolite; and minor pegmatite and aplite bodies arranged parallel to compositional layers. Mica schist is most common in the mass southwest of Dinner Station Campground on the western edge of Taylor Park. Mass on south flank of Mount Yale contains gneissic granite and mixed gneiss (unit Xgn). Protoliths for the metasedimentary gneiss unit likely include graywacke, siliceous graywacke, siltstone, and minor amounts of intermediate-composition volcanic rocks and basalt. Chemical data are not available for most of the rock types. Includes biotite-quartz-plagioclase gneiss of Brock and Barker (1972).

Metasedimentary gneiss along the upper reaches of Sayers Gulch in the Grizzly Peak caldera is extensively brecciated near exposures of felsic porphyry dikes (unit Ttf) of the Twin Lakes pluton. The breccia contains angular fragments of gneiss, but in several areas lacks a matrix, as variously rotated pieces of gneiss abut each other. Brecciation increases in proximity to the felsic porphyry dikes of the Twin Lakes pluton. Gas streaming and fluidization above the advancing magma are believed to have created the breccia that contains no matrix, but solution collapse also could have contributed to the texture of the breccia

$\mathrm{Xq} \quad$ Metasedimentary gneiss and quartzite (Early Proterozoic)-Light-gray to tan, fine-grained to pebbly, undeformed to strongly deformed quartzite, quartz-pebble conglomerate, and mica schist. Quartzite and conglomerate grade into graywacke and siliceous graywacke of unit Xms. Exposed north of Illinois Creek and to the west of Prospector Gulch in Taylor Park and south of Cottonwood Pass. Conglomerate and quartzite beds best developed northeast of Texas Lakes. Aluminous graywacke and pelites most common south of Cottonwood Pass where andalusite, garnet, and sillimanite are noted (Brock and Barker, 1972). Includes 
biotite-muscovite-quartz-plagioclase schist and muscovite-quartz schist units of Brock and Barker (1972). Unit separated from metasedimentary gneiss (unit Xms) because quartzite, conglomerate, and schist more similar to metasedimentary rock units in Fossil Ridge area to southwest (DeWitt and others, 1985) and to schist in the Tincup area to the south (Brock and Barker, 1972)

Xgn Mixed gneiss, mica schist, and gneissic granite (Early Proterozoic)-Mixture of light-gray migmatitic gneiss, mica schist, and gneissic granite. Equivalent to brecciated gneiss unit of Brock and Barker (1972). Exposed in far southeastern part of map area, south of Cottonwood Creek. Not mapped in this study; distribution on map from Brock and Barker (1972)

\section{ACKNOWLEDGMENTS}

Numerous individuals and organizations assisted our mapping in the Collegiate Peaks Wilderness Area and the surrounding parts of the central Sawatch Range. The U.S. Forest Service offices in Leadville, Aspen, Gunnison, and Salida provided assistance in scheduling helicopter flights into the area for mapping and sample collection. We particularly would like to thank Gene Eide, Don Rogers, Jamie Lind, Barney Lyons, and James Paxon, Jr., for their assistance. Personnel from the U.S. Bureau of Mines shared their knowledge of mining activity and mineral prospects in the area. We thank Rick Tschauder, Steve Ludington, Alan Wallace, Jim Shannon, and Rich Van Loenen for sharing their knowledge of ore deposits and regional geology of the area with us. The manuscript was reviewed by Alan Wallace and Karl Evans and benefited from their comments.

\section{REFERENCES CITED}

Aleinikoff, J.N., Reed, J.C., Jr., and DeWitt, Ed, 1993, The Mount Evans batholith in the Colorado Front Range; revision of its age and reinterpretation of its structure: Geological Society of America Bulletin, v. 105, p. 791-806.

Barker, Fred, and Brock, M.R., 1965, Denny Creek Granodiorite Gneiss, Browns Pass Quartz Monzonite, and Kroenke Granodiorite, Mount Harvard Quadrangle, Colorado, in Cohee, G.V., and West, W.S., eds., Changes in stratigraphic nomenclature by the U.S. Geological Survey, 1964: U.S. Geological Survey Bulletin 1224-A, p. A23-A26.
Barker, Fred, Peterman, Z.E., Henderson, W.T., and Hildreth, R.A., 1974, Rubidium-strontium dating of the trondhjemite of Rio Brazos, New Mexico, and of the Kroenke Granodiorite, Colorado: U.S. Geological Survey Journal of Research, v. 2, p. 705-709.

Barker, Fred, Arth, J.G., Peterman, Z.E., and Friedman, Irving, 1976, The 1.7-1.8-b.y.-old trondhjemites of southwestern Colorado and northern New Mexico; Geochemistry and depths of genesis: Geological Society of America Bulletin, v. 87, p. 189-198.

Bickford, M.E., and Boardman, S.J., 1984, A Proterozoic volcano-plutonic terrane, Gunnison and Salida areas, Colorado: Journal of Geology, v. 92, p. 657-666.

Bickford, M.E., Shuster, R.D., and Boardman, S.J., 1989, $\mathrm{U}-\mathrm{Pb}$ geochronology of the Proterozoic volcanoplutonic terrane in the Gunnison and Salida areas, Colorado, in Grambling, J.A., and Tewksbury, B.J., eds., Proterozoic geology of the southern Rocky Mountains: Geological Society of America Special Paper 235, p. 33-48.

Brock, M.R., and Barker, Fred, 1972, Geologic map of the Mount Harvard Quadrangle, Chaffee and Gunnison Counties, Colorado: U.S. Geological Survey Geologic Quadrangle Map GQ-952, scale 1:62,500.

Bryant, Bruce, 1970, Geologic map of the Hayden Peak quadrangle, Pitkin and Gunnison Counties, Colorado: U.S. Geological Survey Geologic Quadrangle Map GQ-863, scale 1:24,000.

1971, Geologic map of the Aspen quadrangle, Pitkin County, Colorado: U.S. Geological Survey Geologic Quadrangle Map GQ-933, scale 1:24,000.

1979, Geology of the Aspen 15-minute quadrangle, Pitkin and Gunnison Counties, Colorado: U. S. Geological Survey Professional Paper 1073, 146 p.

Bryant, Bruce, and Naeser, C.W., 1980, The significance of fission-track ages of apatite in relation to the tectonic history of the Front and Sawatch Ranges, Colorado: Geological Society of America Bulletin, v. 91, p. 156-164.

Bryant, Bruce, Naeser, C.W., and Stegen, R.G., 1990, Reconnaissance fission-track geochronology of the Aspen mining district, central Colorado, in Beaty, D. W., Landis, G. P., and Thompson, T. B., eds., Carbonate-hosted sulfide deposits of the Colorado Mineral Belt: Economic Geology Monograph 7, p. 301-307.

Campbell, D.L., 1981, Aeromagnetic and complete Bouger gravity anomaly maps of the Hunter-Fryingpan Wilderness Area, Pitkin County, Colorado: U.S. Geological Survey Miscellaneous Field Studies Map MF-1236-C, 2 sheets, scale 1:50,000.

Campbell, D.L., and Wallace, A.R., 1986, Aeromagnetic map of the Holy Cross Wilderness Area, Eagle, Lake, and Pitkin Counties, Colorado: U.S. Geological Survey Miscellaneous Field Studies Map MF-1841-B, scale $1: 100,000$. 
Candee, C.R., 1971, The geology of the Lincoln Gulch stock, Pitkin County: Golden, Colorado School of Mines, M.S. thesis, $88 \mathrm{p}$.

Chapman, E.P., 1935, The quartz monzonite batholithic intrusion of Twin Lakes and Clear Creek districts, Lake and Chaffee Counties, Colorado: Colorado Scientific Society Proceedings, v. 13, no. 8, p. 482-493.

Coleman, S.M., McCalpin, J.P., Ostenaa, D.A., and Kirkham, R.M., 1985, Map showing upper Cenozoic rocks and deposits and Quaternary faults, Rio Grande Rift, south-central Colorado: U.S. Geological Survey Miscellaneous Investigations Map I-1594, scale 1:125,000, 2 sheets.

Cruson, M.G., 1973, Geology and ore deposits of the Grizzly Peak cauldron complex, Sawatch Range, Colorado: Golden, Colorado School of Mines, Ph.D. thesis, 180 p.

Cunningham, C.G., Jr., 1976, Petrogenesis and postmagmatic geochemistry of the Italian Mountain intrusive complex, eastern Elk Mountains, Colorado: Geological Society of America Bulletin, v. 86, p. 897-908.

Cunningham, C.G., Jr., and Naeser, C.W., 1975, The Italian Mountain intrusive complex, west-central Colorado, in Cohee, G.V., and Wright, W.B., eds., Changes in stratigraphic nomenclature by the U.S. Geological Survey, 1974: U.S. Geological Survey Bulletin 1405-A, p. 27-28.

Cunningham, C.G., Jr., Naeser, C.W., Marvin, R.F., Luedke, R.G., and Wallace, A.R., 1995, Ages of selected intrusive rocks and associated ore deposits in the Colorado mineral belt: U.S. Geological Survey Bulletin 2109, 31 p.

Dalrymple, G.B., and Lanphere, M.A., 1974, ${ }^{40} \mathrm{Ar}-{ }^{39} \mathrm{Ar}$ age spectra of some undisturbed terrestrial samples: Geochimica et Cosmochimica Acta, v. 38, p. 715-738.

De la Roche, H., Leterrier, J., Grandclaude, P., and Marchal, M., 1980, A classification of volcanic and plutonic rocks using $R_{1} R_{2}$-diagram and major-element analyses--its relationships with current nomenclature: Chemical Geology, v. 29, p. 183-210.

DeWitt, Ed, Stoneman, R.J., Clark, J.R., and Kluender, S.E., 1985, Mineral resource potential of the Fossil Ridge Wilderness Study Area, Gunnison County, Colorado: U.S. Geological Survey Miscellaneous Field Studies Map MF-1629-A, 21 p., 1 plate, scale 1:50,000.

DeWitt, Ed, 1989, Geochemistry and tectonic polarity of Early Proterozoic (1700-1750-Ma) plutonic rocks, north-central Arizona, in Jenney, J.P. and Reynolds, S.J., eds., Geologic evolution of Arizona: Arizona Geological Society Digest 17, p. 149-164.

Dings, M.G., and Robinson, C.S., 1957, Geology and ore deposits of the Garfield quadrangle, Colorado: U.S. Geological Survey Professional Paper 289, 110 p.

Doe, B.R., and Pearson, R.C., 1969, U-Th-Pb chronology of zircons from the St. Kevin Granite, northern Sawatch Range, Colorado: Geological Society of America Bulletin, v. 80 , p. $2495-2502$.
Farmer, G.L., and DePaolo, D.J., 1984, Origin of Mesozoic and Tertiary granite in the western United States and implications for pre-Mesozoic crustal structure; $2, \mathrm{Nd}$ and $\mathrm{Sr}$ isotopic studies of unmineralized and $\mathrm{Cu}$ - and Mo-mineralized granite in the Precambrian craton: Journal of Geophysical Research, v. 89, p. 10,14110,160 .

Fridrich, C.J., 1986, The Grizzly Peak cauldron, Colorado--Structure and petrology of a deeply dissected resurgent ash-flow caldera: Stanford, California, Stanford University, Ph.D. dissertation, 201 p.

Fridrich, C.J., and Mahood, G.A., 1984, Reverse zoning in the resurgent intrusions of the Grizzly Peak cauldron, Sawatch Range, Colorado: Geological Society of America Bulletin, v. 95, p. 779-787.

Fridrich, C.J., Smith, R.P., DeWitt, Ed, and McKee, E.H., 1991, Structural, eruptive, and intrusive evolution of the Grizzly Peak caldera, Sawatch Range, Colorado: Geological Society of America Bulletin, v. 103, p. 1160-1177.

Godson, R.H., Plesha, T.L., Sneddon, R.A., and Krizman, R.W., 1985, Aeromagnetic map of Mount Massive and vicinity, Colorado: U.S. Geological Survey Open-File Report 85-735, scale 1:125,000.

Gunow, A.J., 1983, Trace element mineralogy in the porphyry molybdenum environment: Boulder, University of Colorado, Ph.D. dissertation, $267 \mathrm{p}$.

Hedlund, D.C., 1985, Geologic map of the Buffalo Peaks Wilderness Study Area, Lake, Park, and Chaffee Counties, Colorado: U. S. Geological Survey Miscellaneous Field Studies Map MF-1628-C, scale 1:50,000.

Holtzclaw, M.J., 1973, Geology, alteration, and mineralization of the Red Mountain stock, Grizzly Peak cauldron complex, Colorado: Stillwater, Oklahoma State University, M.S. thesis, $79 \mathrm{p}$.

Knopf, Adolph, 1926, Recent developments in the Aspen district, Colorado: U.S. Geological Survey Bulletin 785 , p. 1-28.

Ludington, Steve, and Yeoman, R.A., 1980, Geologic map of the Hunter-Fryingpan Wilderness Area and the Porphyry Mountain Wilderness Study Area, Pitkin County, Colorado: U.S. Geological Survey Miscellaneous Field Studies Map MF-1236-A, scale 1:50,000.

Ludwig, K.R., 1990, ISOPLOT for MS-DOS, a plotting and regression program for radiogenic isotope data, for IBM-PC compatible computers, v. 2.00: U.S. Geological Survey Open-File Report 88-557, 40 p. and floppy disk.

Marvin, R.F., Young, E.J., Mehnert, H.H., and Naeser, C.W., 1974, Summary of radiometric age determinations on Mesozoic and Cenozoic igneous rocks and uranium and base metal deposits in Colorado: Isochron/West, no. 11, p. 1-41.

Marvin, R.F., Mehnert, H.H., Naeser, C.W., and Zartman, R.E., 1989, U.S. Geological Survey radiometric ages, 
compilation C-Part five; Colorado, Montana, Utah, and Wyoming: Isochron/West, no. 53, p. 14-19.

Moorbath, S., Hurley, P.M., and Fairbairn, H.W., 1967, Evidence for the origin and age of some mineralized Laramide intrusives in the southwestern United States from strontium isotope and rubidium-strontium measurements: Economic Geology, v. 62, p. 228-236.

Mosier, Elwin, Ludington, Steve, and Yeoman, R.A., 1980, Analyses of rocks and stream sediments from the Hunter-Fryingpan Wilderness Area and the Porphyry Mountain Wilderness Study Area, Pitkin County, Colorado: U.S. Geological Survey Open-File Report 80-880, $116 \mathrm{p}$.

Noblett, J.B., Cullers, R.L., and Bickford, M.E., 1987, Proterozoic crystalline rocks in the Wet Mountains and vicinity, central Colorado: New Mexico Geological Survey Guidebook, 38th Field Conference, p. 73-82.

Obradovich, J.D., Mutschler, F.E., and Bryant, Bruce, 1969, Potassium-argon ages bearing on the igneous and tectonic history of the Elk Mountains and vicinity, Colorado; a preliminary report: Geological Society of America Bulletin, v. 80, p. 1749-1756.

Pearson, R.C., Hedge, C.E., Thomas, H.H., and Stern, T.W., 1966, Geochronology of the St. Kevin Granite and neighboring Precambrian rocks, northern Sawatch Range, Colorado: Geological Society of America Bulletin, v. 77, p. 1109-1120.

Pearson, R.C., Tweto, Ogden, Stern, T.W., and Thomas, H.H., 1962, Age of Laramide porphyries near Leadville, Colorado, in Short papers in geology and hydrology: U.S. Geological Survey Professional Paper 450-C, p. C78-C80.

Perkins, R.A., 1973, Trace metal geochemistry and hydrothermal alteration of three molybdenum-bearing stocks, Gunnison and Pitkin Counties, Colorado: Stillwater, Oklahoma State University, M.S. thesis, 78 p.

Ranta, D.E., 1974, Geology, alteration, and mineralization of the Winfield (La Plata) district, Chaffee County, Colorado: Golden, Colorado School of Mines, Ph.D. dissertation, $261 \mathrm{p}$.

Reed, J.C., Jr., Bickford, M.E., Premo, W.R., Aleinikoff, J.N., and Pallister, J.S., 1987, Evolution of the Early Proterozoic Colorado province; constraints from $\mathrm{U}-\mathrm{Pb}$ geochronology: Geology, v. 15, p. 861-865.

Shannon, J.R., 1988, Geology of the Mount Aetna cauldron complex, Sawatch Range, Colorado: Golden, Colorado School of Mines, Ph.D. dissertation, 434 p.

Shannon, J.R., Naeser, C.W., DeWitt, Ed, and Wallace, A.R., 1987, Timing of Cenozoic magmatism and tectonism in the Sawatch Uplift and northern Rio Grande Rift, Colorado [abs.]: Geological Society of America Abstracts with Programs, v. 19, p. 839.

Simmons, E.C., and Hedge, C.E., 1978, Minor-element and Sr-isotope geochemistry of Tertiary stocks, Colorado
Mineral Belt: Contributions to Mineralogy and Petrology, v. 67, p. 379-396.

Steiger, R.H., and Jäger, E., 1977, Subcommission on geochronology--convention and use of decay constants in geo- and cosmochronology: Earth and Planetary Science Letters, v. 36, p. 359-362.

Stein, H.J., and Crock, J.G., 1990, Late Cretaceous-Tertiary magmatism in the Colorado Mineral Belt; rare earth element and samarium-neodymium isotopic studies, in Anderson, J.L., ed., The nature and origin of Cordilleran magmatism: Geological Society of America Memoir 174, p. 195-223.

Toulmin, Priestley, III, and Hammarstrom, J.M., 1990, Geology of the Mount Aetna volcanic center, Chaffee and Gunnison Counties, Colorado: U.S. Geological Survey Bulletin 1864, $44 \mathrm{p}$.

Tweto, Ogden, 1973, Geologic map of the Mount Elbert 15-minute quadrangle, Colorado: U.S. Geological Survey Open-File Report, scale 1:62,500.

1974, Geologic map and sections of the Holy Cross quadrangle, Eagle, Lake, Pitkin, and Summit Counties, Colorado: U.S. Geological Survey Miscellaneous Investigations Series Map I-830, scale 1:24,000.

1979, Geologic map of Colorado: U.S. Geological Survey, scale 1:500,000.

Tweto, Ogden, and Case, J.E., 1972, Gravity and magnetic features as related to geology in the Leadville 30-minute quadrangle, Colorado: U.S. Geological Survey Professional Paper 726-C, p. C1-C3.

Tweto, Ogden, Moench, R.H., and Reed, J.C., Jr., 1978, Geologic map of the Leadville $1^{\circ} \times 2^{\circ}$ Quadrangle, northeastern Colorado: U.S. Geological Survey Miscellaneous Investigations Series Map I-999, scale $1: 250,000$.

Tweto, Ogden, and Pearson, R.C., 1964, St. Kevin Granite, Sawatch Range, Colorado, in Short papers in geology and hydrology: U.S. Geological Survey Professional Paper 475-D, p. D28-D32.

Tweto, Ogden, Steven, T.A., Hail, W.J., Jr., and Moench, R.H., 1976, Preliminary geologic map of the Montrose $1^{\circ} \times 2^{\circ}$ quadrangle, southwestern Colorado: U.S. Geological Survey Miscellaneous Field Studies Map MF-761, scale 1:250,000.

Van Loenen, R.E., 1985, Geologic map of the Mount Massive Wilderness, Lake County, Colorado: U.S. Geological Survey Miscellaneous Field Studies Map MF-1792-A, scale 1:50,000.

Van Loenen, R.E., Lee, G.K., Campbell, D.L., and Thompson, J.R., 1989, Mineral resource potential of Mount Massive Wilderness, Lake County, Colorado: U.S. Geological Survey Bulletin 1636, 18 p.

Wallace, A.R., 1993, Summary of radiometric geochronologic data and related information, Leadville $1^{\circ}$ by $2^{\circ}$ quadrangle, Colorado: U.S. Geological Survey Open-File Report 93-343, 1 diskette. 
1995, Isotopic geochronology of the Leadville $1^{\circ}$ by $2^{\circ}$ quadrangle, west-central Colorado-summary and discussion: U.S. Geological Survey Bulletin 2104, 51 p.

Wallace, A.R., Blaskowski, M.J., and Pearson, R.C., 1986, Geologic map of the Holy Cross Wilderness, Eagle, Pitkin, and Lake Counties, Colorado: U.S. Geological Survey Miscellaneous Field Studies Map MF-1841-A, scale 1:50,000.

Wallace, A.R., and Blaskowski, M.J., 1989, Geologic map of the Mount Jackson quadrangle and the eastern part of the Crooked Creek Pass quadrangle, Eagle County, Colorado: U.S. Geological Survey Miscellaneous Investigations Series Map I-1909, scale 1:24,000.
Wetherill, G.W., and Bickford, M.E., 1965, Primary and metamorphic $\mathrm{Rb}-\mathrm{Sr}$ chronology in central Colorado: Journal of Geophysical Research, v. 70, no. 18, p. 4669-4686.

Wilshire, H.G., 1969, Mineral layering in the Twin Lakes granodiorite, Colorado, in Larsen, L.H., Prinz, Martin, and Manson, Vincent, eds., Igneous and metamorphic geology, a volume in honor of Arie Poldervaart: Geological Society of America Memoir 115, p. 236-261.

Zoerner, F.P., 1974, The geology of the central Elk Mountains, Colorado: Laramie, University of Wyoming, M.S. thesis, $117 \mathrm{p}$. 
